\title{
Interaction between 24-hydroxycholesterol, oxidative stress, and amyloid- $\beta$ in amplifying neuronal damage in Alzheimer's disease: three partners in crime
}

Paola Gamba, ${ }^{1}$ * Gabriella Leonarduzzi, ${ }^{1}$ * Elena Tamagno, ${ }^{2}$ Michela Guglielmotto, ${ }^{2}$ Gabriella Testa, ${ }^{1}$ Barbara Sottero, ${ }^{1}$ Simona Gargiulo, ${ }^{1}$ Fiorella Biasi, ${ }^{1}$ Alessandro Mauro, ${ }^{3}$ José Viña ${ }^{4}$ and Giuseppe Poli ${ }^{1}$

${ }^{1}$ Department of Clinical and Biological Sciences, Faculty of Medicine San Luigi Gonzaga, University of Turin, Turin, Italy ${ }^{2}$ Department of Experimental Medicine and Oncology, University of Turin, Turin, Italy

${ }^{3}$ Division of Neurology and Neurorehabilitation, IRCCS Istituto Auxologico Italiano, Verbania, Italy and Department of Neurosciences, University of Turin, Turin, Italy

${ }^{4}$ Department of Physiology, Faculty of Medicine, University of Valencia, Valencia, Spain

\section{Summary}

All three cholesterol oxidation products implicated thus far in the pathogenesis of Alzheimer's disease, 7 $\beta$-hydroxycholesterol, 24-hydroxycholesterol, and 27-hydroxycholesterol, markedly enhance the binding of amyloidbeta $(A \beta)$ to human differentiated neuronal cell lines (SK-N-BE and NT-2) by up-regulating net expression and synthesis of CD36 and $\beta 1$-integrin receptors. However, only 24-hydroxycholesterol markedly potentiates the proapoptotic and pro-necrogenic effects of $A \beta_{1-42}$ peptide on these cells: 7 7 -hydroxycholesterol and 27-hydroxycholesterol, like unoxidized cholesterol, show no potentiating effect. This peculiar behavior of 24-hydroxycholesterol at physiologic concentrations $(1 \mu \mathrm{M})$ depends on its strong enhancement of the intracellular generation of NADPH oxidase-dependent reactive oxygen species (ROS), mainly $\mathrm{H}_{2} \mathrm{O}_{2}$, and the consequent impairment of neuronal cell redox equilibrium, measured in terms of the GSSG/GSH ratio. Cell incubation with antioxidants quercetin or genistein prevents 24-hydroxycholesterol's pro-oxidant effect and potentiation of $\mathbf{A} \beta$-induced necrosis and apoptosis. Thus, the presence of 24-hydroxycholesterol in the close vicinity of amyloid plaques appears to enhance the adhesion of large amounts of $A \beta$ to the plasma membrane of neurons and then to amplify the neurotoxic action of $A \beta$

\footnotetext{
Correspondence

Giuseppe Poli, MD, Department of Clinical and Biological Sciences, University of Torino, San Luigi Gonzaga Hospital, Regione Gonzole 10, 10043 Orbassano, Torino, Italy. Tel.: +39011 6705422; fax: +39 011 6705424; e-mail: giuseppe.poli@unito.it

*These authors contributed equally to the work.
}

Accepted for publication 4 January 2011 by locally increasing ROS steady-state levels. This report further supports a primary involvement of altered brain cholesterol metabolism in the complex pathogenesis of Alzheimer's disease.

Key words: cholesterol; Alzheimer's disease; oxysterols; amyloid- $\beta$; oxidative stress; neurotoxicity.

\section{Introduction}

Alzheimer's disease (AD), a protein misfolding disorder, is the commonest type of dementia in developed countries; it is characterized by progressive neuronal degeneration, gliosis, and the accumulation of intracellular inclusions (neurofibrillary tangles) and extracellular deposits of amyloid- $\beta$ (senile plaques) in the discrete regions of the basal forebrain, hippocampus, and association cortices (Selkoe, 1991; Hashimoto et al., 2003). Amyloid- $\beta \quad(A \beta)$ is also deposited in the cerebral vessels. Accumulation of $A \beta$ peptides is thought to be an early and causative event in $A D$ pathogenesis and increases markedly during disease progression (Selkoe, 1994).

Several intertwined causative factors lead to the development of $A D$, including increased release and polymerization of $A \beta$, hypertension, advanced glycation end-products, oxidative stress, inflammation, and hypercholesterolemia (Querfurth \& LaFerla, 2010). At least three important lines of evidence have implicated cholesterol in AD: (i) hypercholesterolemia is unanimously recognized to be a risk factor for sporadic $A D$, a form that accounts for the great majority of cases (Puglielli et al., 2003; Panza et al., 2007); (ii) epidemiological studies have shown homozygosity for the APO-E4 allele (APO-E \&4 genotype) to be associated with an increased risk of $A D$ (Corder et al., 1993; Evans et al., 2004); (iii) feeding cholesterol and copper to rabbits produces some of the pathological signs of $A D$ including amyloid-like plaques (Sparks \& Schreurs, 2003). In addition, early epidemiological studies indicated that cholesterol-lowering agents belonging to the family of statins reduce the prevalence of $A D$ (Jick et al., 2000), a conclusion not yet fully accepted, because of contradictory results of prospective clinical studies (Kandiah \& Feldman, 2009).

The brain is the organ with the highest concentration of cholesterol, which is essential for its normal function; most of the cholesterol is present in the free form and derives from de novo synthesis by astrocytes, as plasma lipoproteins cannot cross the blood-brain barrier (Puglielli et al., 2003). Cholesterol can only efflux to the plasma in normal conditions if it is transformed into oxysterols, cholesterol oxidation products that are thus impor- 
tant to balance the local synthesis of sterols (Lütjohann et al., 1996).

The major oxysterol involved in this excretion mechanism appears to be 24-hydroxycholesterol (24-OH), also known as cerebrosterol, which is produced almost exclusively in the brain by cholesterol 24-hydroxylase (cytochrome $\mathrm{P}_{450}$-46A1) (Björkhem \& Meaney, 2004; Björkhem, 2006). Another oxysterol, 27-hydroxycholesterol (27-OH), has been found to be produced in situ in the brain by the cytochrome $\mathrm{P}_{450}-27 \mathrm{~A} 1$, or even, unlike its parent compound, to flow from the circulation into the brain (Heverin et al., 2005). A third compound, 7 $\beta$-hydroxycholesterol $(7 \beta-\mathrm{OH})$, may derive in the brain from the oxidation of cholesterol by $A \beta$ and, to a lesser extent, by amyloid precursor protein (Nelson \& Alkon, 2005).

Notably, an increased concentration of $24-\mathrm{OH}$ has been detected in the cerebrospinal fluid of patients with $A D$ (Schönknecht et al., 2002), while decreased 24-OH and increased $27-\mathrm{OH}$ are consistently found in autoptic brain samples from patients with AD (Heverin et al., 2004). Further, an abnormal pattern of cholesterol hydroxylases has been observed in the $A D$ brain, with a prominent expression of 24-hydroxylase in astrocytes and around amyloid plaques (Brown et al., 2004). Hence, changes in the brain cholesterol/oxysterol balance, with pathological accumulation of cholesterol oxides in the Central Nervous System, may be the missing link between hypercholesterolemia and AD.

Oxysterols, which may either originate in the body or derive from the diet, are 27-carbon molecules produced by the oxidation of cholesterol. It is widely accepted that both enzymatic and nonenzymatic reactions are responsible for oxysterol generation in the body (Leonarduzzi et al., 2002; Poli et al., 2009). Enzymatic processes mainly involve the side chain of cholesterol yielding $24-\mathrm{OH}$ and $27-\mathrm{OH}$. On the contrary, oxidation of the sterol nucleus, which primarily occurs at position 7 or at the 5,6 double bond, is commonly a nonenzymatic (autooxidative) reaction and generates, among others, $7 \beta-\mathrm{OH}$ of probable interest in the pathogenesis of neurodegenerative diseases. A typical nonenzymatic oxidation process of cholesterol is that mediated by inflammatory cells undergoing oxidative burst. Oxysterols have been shown to exert several in vitro and in vivo biochemical activities of both physiologic and pathologic relevance (Sottero et al., 2009). Particularly relevant is the strong pro-inflammatory action shown by several components of this class of compounds (Vejux \& Lizard, 2009). Thus, inflammation readily generates oxysterols that in turn up-regulate the flogistic process.

To determine how the oxysterols $24-\mathrm{OH}, 27-\mathrm{OH}$, and $7 \beta-\mathrm{OH}$ could modulate and perhaps amplify the expression of $A D$, we investigated the potential interaction between these cholesterol oxides and $A \beta$, whose extracellular accumulation in neuritic plaques is one of the hallmarks of $A D$. A possible manner of interaction could be by enhancing binding to $A \beta$ toxic peptides by vicinal neuronal cells. To date, this event has been demonstrated to occur for another cell type, namely microglia: human THP-1 monocytes and murine microglial cells have been shown to readily bind to the fibrillar form of $A \beta$, through a receptor complex involving CD36, $\alpha 6 \beta 1$-integrin, and CD47 (Bamberger et al., 2003).

On the basis of our recent demonstration that certain cholesterol oxidation products, unlike the parent compound, markedly up-regulate both the expression and the synthesis of CD36 in the cells of the macrophage lineage (Leonarduzzi et al., 2008), we decided to investigate whether oxysterols also exert the same effect on neuronal cells.

All three cholesterol oxidation products considered strongly enhanced the binding of $A \beta$ to human differentiated neuronal cell lines (SK-N-BE and NT-2), by strongly up-regulating expression and synthesis not only of CD36 but also of $\beta 1$-integrin receptors. However, only the combination of $24-\mathrm{OH}$ plus the $A \beta_{1-42}$ peptide exerted net neurotoxicity. The reason for this selective behavior of $24-\mathrm{OH}$ turned out to be dependent on its strong pro-oxidant action.

\section{Results}

\section{7-OH, 7 $-\mathrm{OH}$, and 24-OH up-regulate the expression of the CD36 and $\beta 1$-integrin genes, but not that of the CD47 gene, in SK-N-BE and NT-2 neuronal cells}

The three oxysterols considered as being potentially implicated in the pathogenesis of Alzheimer's disease were first checked for their ability to modulate the CD36/ $\beta 1$-integrin/CD47 receptor complex in two differentiated human neuronal cell lines, namely SK-N-BE and NT-2 cells.

In SK-N-BE cells, a statistically significant increase (about 1.5 to 2 -fold induction, $P<0.001-0.05$ ) in CD36 mRNA and $\beta 1$-integrin mRNA levels was evident after $5 \mathrm{~h}$ cell incubation with any of the three oxysterols in biologically compatible concentrations ( $1 \mu \mathrm{m}$ ) compared with control. Of interest, this overexpression appeared to occur in a synchronous manner and was not inducible even minimally when oxysterols were replaced by an identical amount of unoxidized cholesterol (Fig. 1A). A trend to increased CD36 mRNA and $\beta 1$-integrin mRNA levels was consistently observed also in NT-2 neuronal cells after $4 \mathrm{~h}$ cell incubation with $7 \beta-\mathrm{OH}$ or $24-\mathrm{OH}$, even if statistically significant (about 2-fold induction compared with control, $P<0.001$ and $P<0.01)$ only in the latter case. As regards $27-\mathrm{OH}$, it appeared to increase the expression of $\beta 1$-integrin and not that of CD36 (Fig. 1B). Expression of the CD47 gene was in no case modulated by any of the three oxysterols considered in this study, neither in SK-N-BE nor in NT-2 cells (Fig. 2).

\section{7-OH, 7 $\beta-\mathrm{OH}$, and 24-OH increase CD36 and $\beta 1$ - integrin synthesis}

A statistically significant increase $(P<0.001$ and $P<0.05$ vs. control) in the synthesis of the two receptors corresponded to the over-expression of CD36 and $\beta 1$-integrin genes, in both SK-N-BE and NT-2 neuronal cells, measured by Western blotting after $48 \mathrm{~h}$ treatment with $27-\mathrm{OH}, 7 \beta-\mathrm{OH}$, or $24-\mathrm{OH}$. Of note, 
(A)
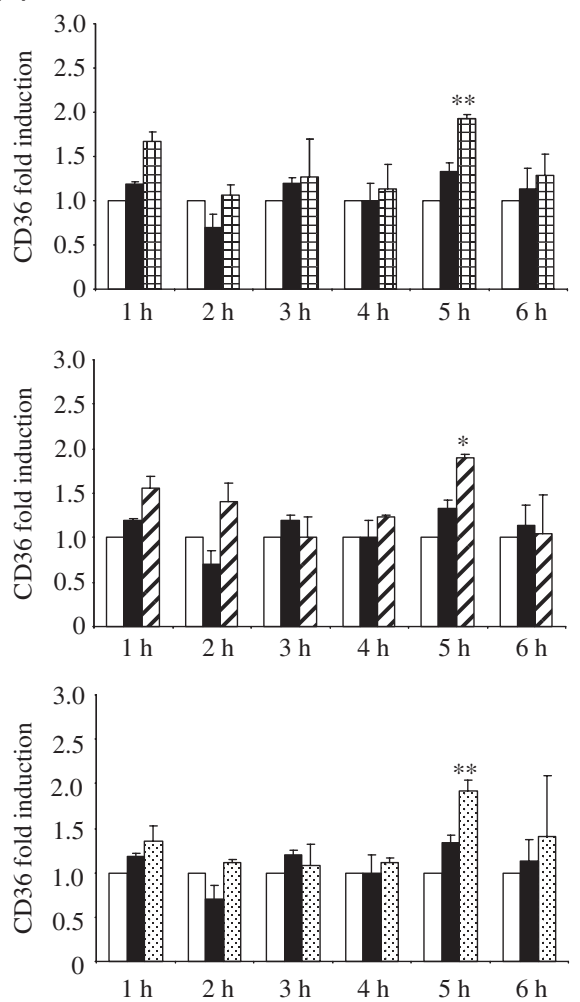

(B)
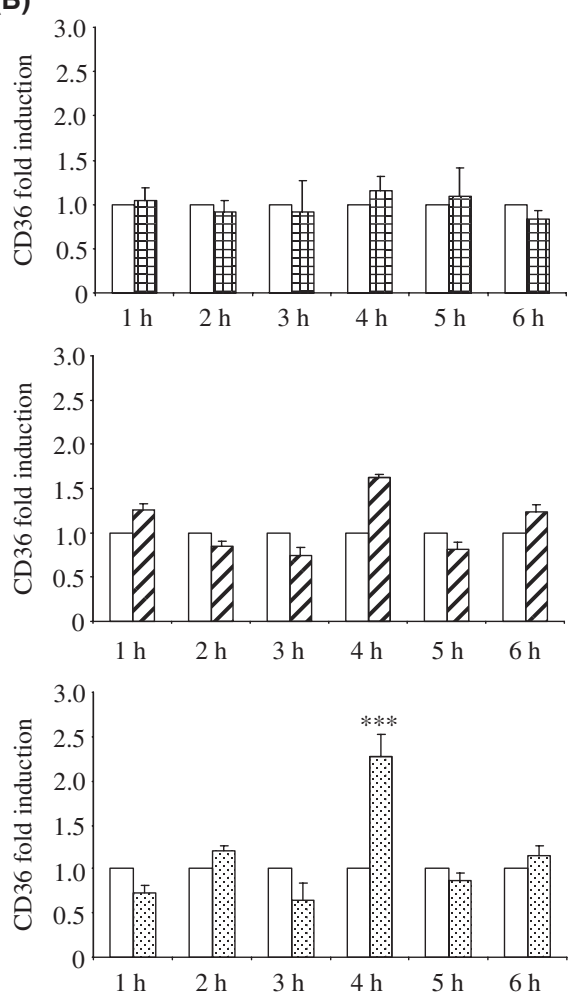

SK-N-BE
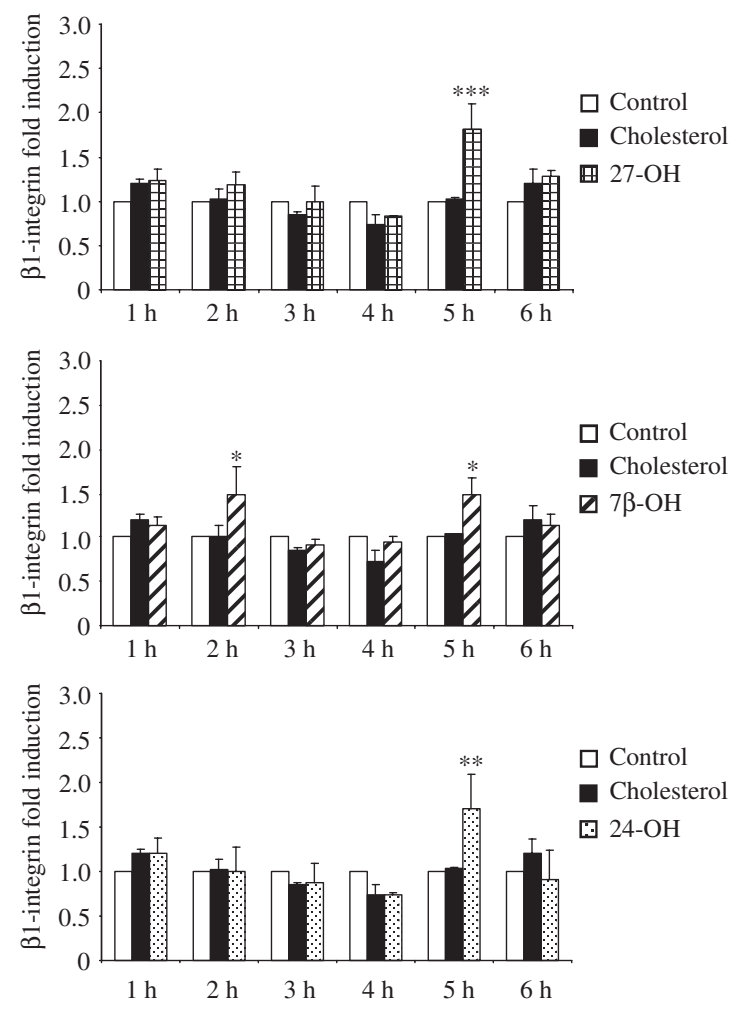

NT-2
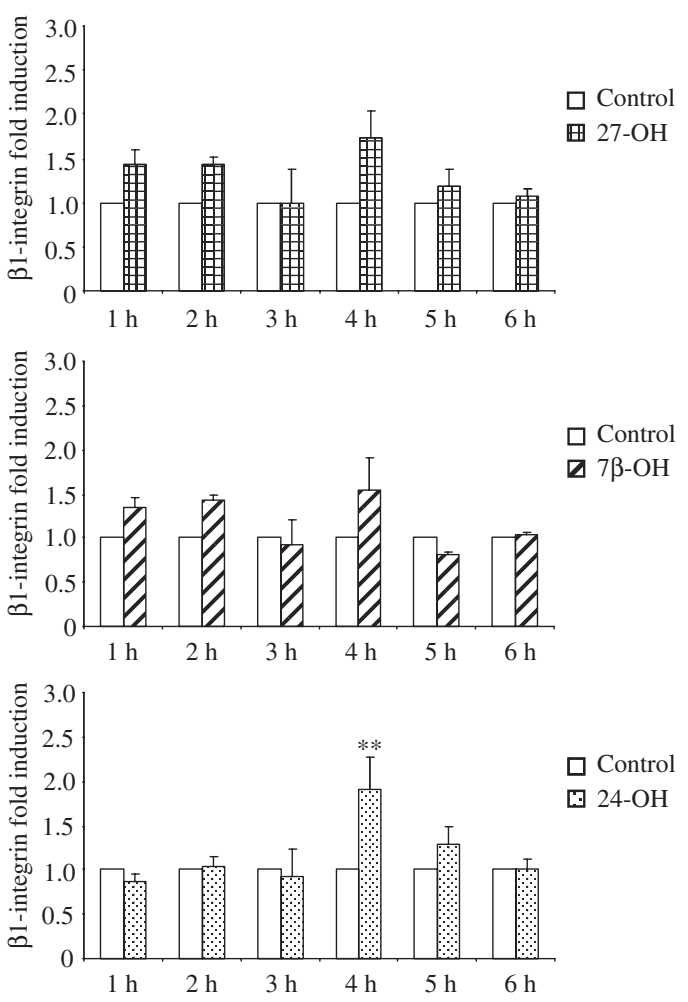

Fig. 1 Effect of 27-hydroxycholesterol (27-OH), 7 $\beta$-hydroxycholesterol (7 $\beta$-OH), and 24-hydroxycholesterol (24-OH) on the expression of $\mathrm{CD} 36$ and $\beta 1$-integrin receptors. Gene expression was quantified by real-time RT-PCR in SK-N-BE (A) and NT-2 (B) cells treated for times up to 6 h with $1 \mu \mathrm{m} 27-\mathrm{OH}$, 7 $3-\mathrm{OH}$, or 24-OH or with $1 \mu \mathrm{m}$ cholesterol (only SK-N-BE cells). Untreated cells were taken as control. Data, normalized to $\beta 2$-microglobulin, are expressed as mean values \pm standard deviation of three different experiments. ${ }^{*} P<0.05, * * P<0.01$, and ${ }^{* * *} P<0.001$ vs. control group. 
the effects of the three oxysterols on CD36 and $\beta 1$-integrin synthesis appeared quantitatively quite similar: about 150-190\% (SK-N-BE) and 300\% (NT-2) the increment of CD36 levels and $180-250 \%$ (SK-N-BE) and $250 \%$ (NT-2) the increment of $\beta 1$-integrin levels vs. control taken as 100\% (Fig. 3).

\section{AD-relevant oxysterols strongly enhance the adhesion of neuronal cells to amyloid- $\beta$; the effect is mediated by up-regulation of CD36 and $\beta 1$-integrin receptors}

The consequence of increased availability of CD36 and $\beta 1$-integrin receptors, in terms of binding to $A \beta$, was investigated on SK-N-BE neuronal cells incubated for $48 \mathrm{~h}$ in the presence of 27 $\mathrm{OH}, 7 \beta-\mathrm{OH}$, or $24-\mathrm{OH}$ and then challenged for $8 \mathrm{~h}$ with the $A \beta_{1-42}$ peptide. The binding of $A \beta_{1-42}$ (detected by confocal microscopy) to neuronal cells was greatly stimulated by cell pretreatment with any of the three oxysterols vs. that recovered in cells either untreated or simply incubated with unoxidized cholesterol (Fig. 4). This marked enhancement of $A \beta_{1-42}$ peptide binding was fully prevented by the addition of either anti-CD36or anti- $\beta 1$-integrin-specific antibodies to the incubation medium before the challenge with the $A \beta_{1-42}$ peptide (Fig. 4). At Congo red staining, SK-N-BE neuronal cells treated with the oxysterols and then with $A \beta_{1-42}$ showed highly stimulated $A \beta_{1-42}$ binding vs. internal controls (untreated and $A \beta_{1-42}$-treated cells) and vs. unoxidized cholesterol plus $A \beta_{1-42}$-treated cells; the amyloid peptide that bound to the cells was mainly concentrated in clusters (Fig. 5).

\section{Different effects of $27-\mathrm{OH}, 7 \beta-\mathrm{OH}$, and $24-\mathrm{OH}$ in potentiating amyloid- $\beta$ 's necrogenic effect on neuronal cells}

To determine whether increased binding of amyloid- $\beta$ to neuronal cells potentiates the peptide's toxic effects, SK-N-BE and NT-2 cells, differentiated with retinoic acid, were first incubated for $48 \mathrm{~h}$ with one of the three oxysterols and then challenged for $24 \mathrm{~h}$ with $A \beta_{1-42}$ peptide. At the end of the experiment, necrosis was measured by the cell release of lactate dehydrogenase (LDH): 24-OH, not necrogenic per se, increased about 3- to 3.5 -fold $\left(P<0.01\right.$ vs. control) the LDH release induced by $A \beta_{1-}$ 42 , in both SK-N-BE and NT-2 differentiated cells (Fig. 6A,C). On the contrary, neither $27-\mathrm{OH}$, nor $7 \beta-\mathrm{OH}$, nor unoxidized cholesterol caused any significant modulation of the induced LDH release (Fig. 6A,C). As expected, cell treatment with the scramble peptide neither induced nor permitted any change in LDH release.

Importantly, 24-OH's marked potentiation of $A \beta_{1-42}$ 's necrogenic effect was significantly quenched $(30-40 \%$ reduction, $P<0.01)$ compared with $24-\mathrm{OH}$-treated cells, in both neuronal cell lines, by addition of anti-CD36 antibodies, and was fully prevented $(P<0.05)$ by addition of anti- $\beta 1$-integrin-specific antibodies (Fig. 6B,D).
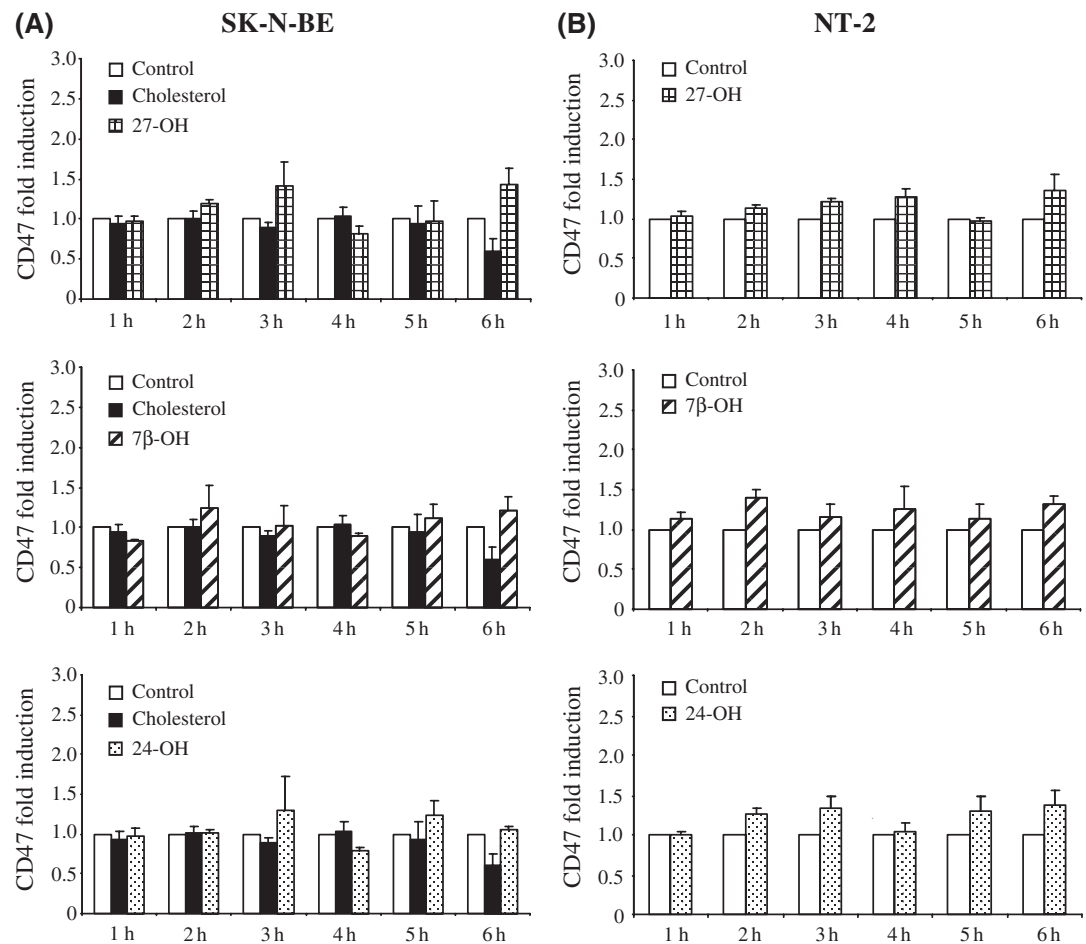

Fig. 2 Effect of 27-hydroxycholesterol (27-OH), 7 $\beta$-hydroxycholesterol (7 $\beta-O H)$, and 24-hydroxycholesterol (24-OH) on the expression of CD47 receptor. Gene expression was quantified by real-time RT-PCR in SK-N-BE (A) and NT-2 (B) cells treated up to 6 h with $1 \mu \mathrm{m} 27-\mathrm{OH}, 7 \beta-\mathrm{OH}$, or 24-OH or with $1 \mu \mathrm{M}$ cholesterol (only SK-N-BE cells). Untreated cells were taken as control. Data, normalized to $\beta 2$-microglubulin, are expressed as mean values \pm standard deviation of three different experiments. 
(A)

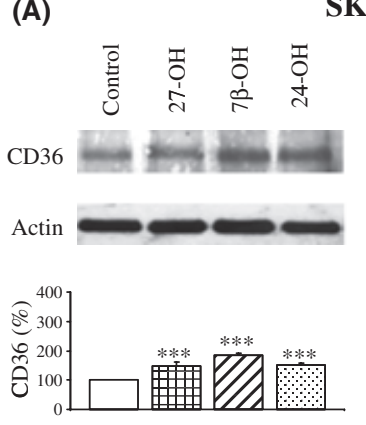

$48 \mathrm{~h}$
SK-N-BE

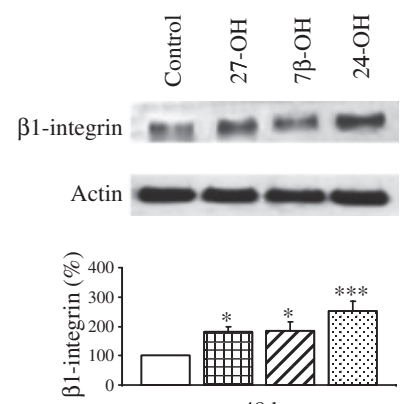

$48 \mathrm{~h}$
(B)
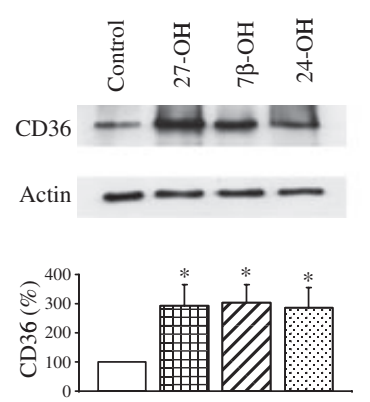

$48 \mathrm{~h}$
NT-2

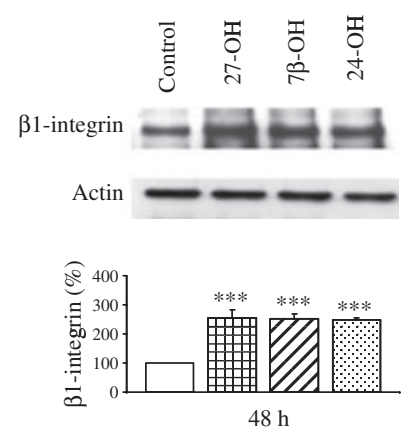

Fig. 3 Effect of 27-hydroxycholesterol (27-OH), 7 $\beta$-hydroxycholesterol $(7 \beta-O H)$, and 24 -hydroxycholesterol $(24-\mathrm{OH})$ on CD36 and $\beta 1$-integrin synthesis. SK-N-BE (A) and NT-2 (B) cells were treated for $48 \mathrm{~h}$ with oxysterols at a final concentration of $1 \mu \mathrm{m}$. Untreated cells were taken as control. CD36 and $\beta 1$-integrin levels were analyzed by Western blotting. Top: blot representative of three experiments. Bottom: histogram representing mean values \pm standard deviation of three experiments. CD36 and $\beta 1$-integrin densitometric measurements were normalized against the corresponding actin levels and expressed as percentage of control value. ${ }^{*} P<0.05$ and $* * * P<0.001$ vs. control.

\section{Pretreatment of neuronal cells with $24-\mathrm{OH}$, but not with $27-\mathrm{OH}, 7 \beta-\mathrm{OH}$, or unoxidized cholesterol, potentiates the Aß-dependent apoptotic effect}

A similar set of data were obtained when AD-relevant oxysterols were examined for their potential enhancement of $A \beta$ 's proapoptotic effect: 4,4-diamidino-2-phenylindole dihydrochloride (DAPI) staining showed that the moderate but consistent apoptotic effect exerted on SK-N-BE cells by $A \beta_{1-42}(15 \%$ DAPIstained cells), but not by the scramble, was markedly increased when cells were incubated with 24-OH (50\% DAPI-stained cells), as was said not toxic per se. On the contrary, neither $27-\mathrm{OH}$ nor $7 \beta-\mathrm{OH}$, exactly like an identical concentration of unoxidized cholesterol, altered the observed $A \beta_{1-42}$ apoptotic effect (Fig. 7A). These findings were fully confirmed on NT-2 neuronal cells challenged with $A \beta_{1-42}$ (Fig. 7C). As in the case of potentiation of $A \beta$ 's necrogenic effect on neuronal cells, both anti-CD36 and anti- $\beta 1$-integrin competitive treatments entirely prevented the appearance of apoptotic bodies in SK-N-BE and NT-2 cultures incubated with $24-\mathrm{OH}$ and then challenged with $A \beta_{1-42}$ (Fig. 7B,D).

\section{Only treatment of neuronal cells with $24-\mathrm{OH}$ induces an oxidative imbalance of the cellular redox equilibrium}

In an attempt to explore the remarkably different behaviors shown by the three oxysterols of interest in $A D$ pathogenesis as regards $A \beta$ 's neurotoxicity, we decided to analyze their potential pro-oxidant effects employing the same cellular models and oxysterol concentrations employed in the rest of this study. Importantly, treatment of both neuronal cell lines with $24-\mathrm{OH}$ produced a strong up-regulation of cell steady-state levels of reactive oxygen species (ROS) measured by both biochemical and fluorescence ( $P<0.05$ vs. control) methods (Figs 8B,D and $9 A, B)$. As a consequence, the redox equilibrium of both SK-N-BE and NT-2 neuronal cells appeared deranged, as indicated by the net increase in the oxidized/reduced glutathione (GSSG/GSH) ratio during cell treatment $(P<0.05$ vs. control) (Fig. $8 \mathrm{~A}, \mathrm{C})$. Unlike what occurred with $24-\mathrm{OH}$, ROS steady-state levels and cellular redox equilibrium did not appear significantly affected by either $27-\mathrm{OH}, 7 \beta-\mathrm{OH}$, or unoxidized cholesterol (Figs 8 and 9).

The incubation of differentiated SK-N-BE neuronal cells with $27-\mathrm{OH}$, or $7 \beta-\mathrm{OH}$, or $24-\mathrm{OH}$ in the presence of $A \beta_{1-42}$ did not significantly modulate GSSG/GSH ratio (Fig. $8 \mathrm{~A}$ ) and $\mathrm{H}_{2} \mathrm{O}_{2}$ production (Fig. 8B) as well as ROS production (Fig. 9C) vs. oxysterol-treated SK-N-BE cells.

To confirm that NADPH oxidase is a primary source of the observed ROS over-production, SK-N-BE cells were pretreated with diphenyleneiodonium (DPI) (5 $\mu \mathrm{M}$ ) or with apocynin (APO) $(300 \mu \mathrm{m})$. Both NADPH oxidase inhibitors were able to block the 24-OH-induced enhancement of ROS production by neuronal cells (Fig. 9D).

\section{The potentiating effect of $24-\mathrm{OH}$ on $\mathrm{A} \boldsymbol{\beta}_{1-42^{-}}$ dependent neurotoxicity appears chiefly dependent on this cholesterol oxidation product's pro-oxidant effect}

To test the possible involvement of the pro-oxidant activity of $24-\mathrm{OH}$ in its potentiating $A \beta$ neurotoxicity, suitable supplementation of the neuronal cell incubation medium was provided, with two flavonoids known to possess strong antioxidant properties, namely quercetin and genistein. Incubation of SK-N-BE and NT-2 differentiated cells, in the presence of either quercetin or genistein, fully prevented the oxidative stress condition generated in the neuronal cell cultures by incubation with $24-\mathrm{OH}$, in terms of ROS production ( $P<0.01$ vs. $24-\mathrm{OH}$-treated cells) (Figs $9 A, B$ and $10 B, D)$ as well as of the GSSG/GSH ratio $(P<0.01$ vs. 24-OH-treated cells) (Fig. 10A,C). More importantly, this flavonoid-mediated inhibition of 24-OH's pro-oxidant effect completely prevented the potentiation exerted by this oxysterol on $\mathrm{A} \beta_{1-42}$ 's necrogenic ( $P<0.01$ vs. $24-\mathrm{OH}+\mathrm{A} \beta_{1-42}$-treated cells) and apoptotic (1-3\% DAPI-stained cells) effects, in both SK-N-BE and NT-2 cells (Fig. 11) 


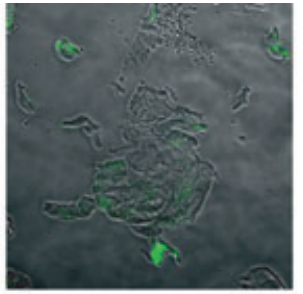

$\mathrm{A} \beta_{1-42}$

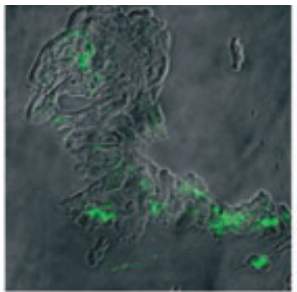

Cholesterol $+\mathrm{A} \beta_{1-42}$

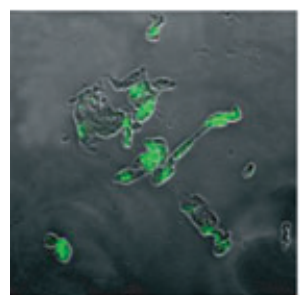

27-OH

$+\mathrm{A} \beta_{1-42}$

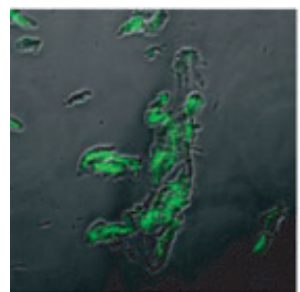

$7 \beta-\mathrm{OH}$

$+\mathrm{A} \beta_{1-42}$

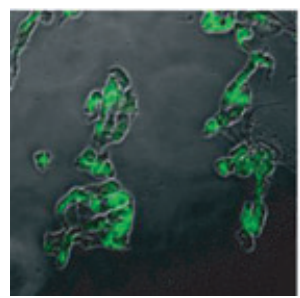

24-OH

$+\mathrm{A} \beta_{1-42}$

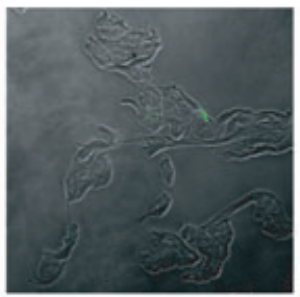

$27-\mathrm{OH}+$ anti-CD36

$+\mathrm{A} \beta_{1-42}$

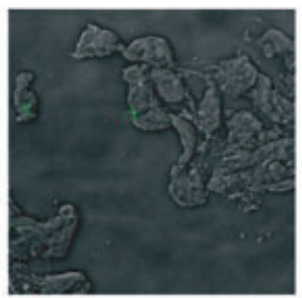

$7 \beta-\mathrm{OH}+$ anti-CD36

$+\mathrm{A} \beta_{1-42}$

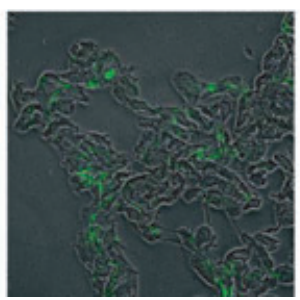

24-OH + anti-CD36

$+\mathrm{A} \beta_{1-42}$

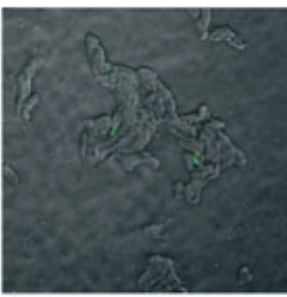

$27-\mathrm{OH}+$ anti- $\beta 1$-integrin $+\mathrm{A} \beta_{1-42}$

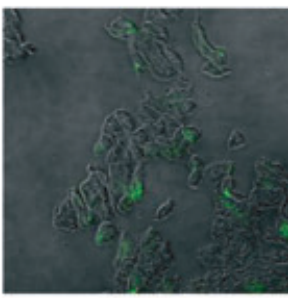

$7 \beta-\mathrm{OH}+$ anti- $\beta 1$-integrin $+\mathrm{A} \beta_{1-42}$

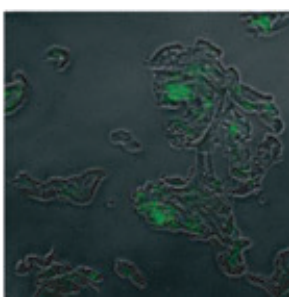

$24-\mathrm{OH}+$ anti- $\beta 1$-integrin

$+\mathrm{A} \beta_{1-42}$

Fig. 4 Oxysterols enhance the adhesion of neuronal cells to amyloid- $\beta$. SK-N-BE cells were incubated for $48 \mathrm{~h}$ in the presence of $1 \mu \mathrm{m}$ of cholesterol, $27-\mathrm{OH}$, $7 \beta-\mathrm{OH}$, or $24-\mathrm{OH}$ and then treated for $8 \mathrm{~h}$ with $1 \mu \mathrm{m} \mathrm{A} \beta_{1-42}$. Some cell aliquots were also pre-incubated for $1 \mathrm{~h}$ with anti-CD36 $\left(2 \mu \mathrm{g} \mathrm{mL} \mathrm{L}^{-1}\right)$ or anti- $\beta 1$-integrin $\left(2 \mu \mathrm{g} \mathrm{mL} \mathrm{m}^{-1}\right)$ antibodies before adding $A \beta_{1-42}$. Cells treated with $1 \mu \mathrm{m} A \beta_{1-42}$ for $8 \mathrm{~h}$ were used as control. $A \beta_{1-42}$ peptide binding was detected by confocal laser microscopy using fluorescein isothiocyanate (FITC) fluorochrome (excitation from the $488 \mathrm{~nm}$ Ar laser line and emission passing through a longpass 505-550 $\mu \mathrm{M}$ filter) and equipped with an inverted microscope with Plan-NEOFLUAR lenses $(20 \times / 0.5,2 \times)$. Images are from one representative experiment.

\section{Discussion}

Altered cholesterol metabolism in the brain has repeatedly been suggested to be implicated in the pathogenesis of Alzheimer's disease, but the molecular mechanisms underlying such an involvement are still largely undefined. A net increase in free cholesterol has been clearly demonstrated in the cerebral cortical tissue of aging mice, in the primary cultures of rat hippocampal neurons exposed to $A \beta$, and in the frontal cortex of autopsyconfirmed patients with AD (Cutler et al., 2004). Interestingly, this cholesterol increase is accompanied by increased ceramide production and is consistently associated, in both experimental models and human autoptic material, with a biochemical condition of oxidative stress, i.e., an imbalance of cell/tissue redox equilibrium toward oxidation (Cutler et al., 2004).

Oxidative stress is increasingly considered to play a pivotal role in the initiation and promotion of the neurodegenerative events that characterize AD (Bonda et al., 2010; Rothman \& Mattson, 2010); it may be triggered within the brain by any environmental or age-related factor that can induce an oxidative burst in the microglia, by inflammatory molecules, and also by $A \beta$ (Zhu et al., 2007a).

The association of oxidative stress with the accumulation of free cholesterol in AD brains should, in principle, facilitate the 


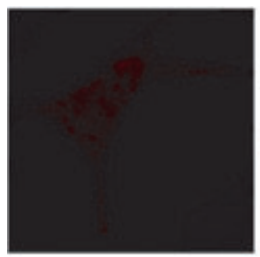

Control

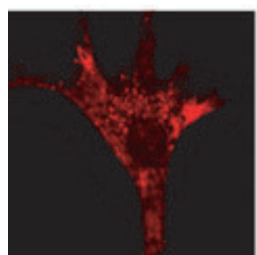

$27-\mathrm{OH}+\mathrm{A} \beta_{1-42}$

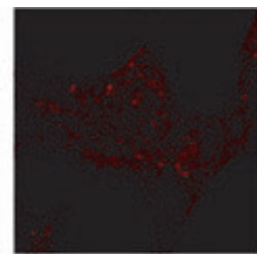

$\mathrm{A} \beta_{1-42}$

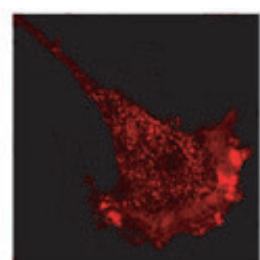

$7 \beta-\mathrm{OH}+\mathrm{A} \beta_{1-42}$

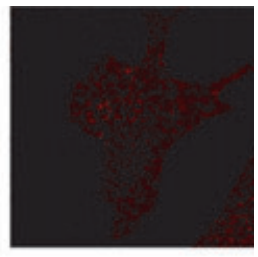

Cholesterol $+\mathrm{A} \beta_{1-42}$

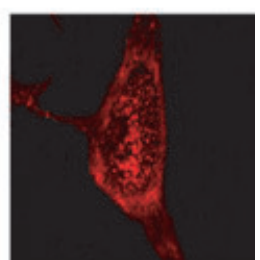

$24-\mathrm{OH}+\mathrm{A} \beta_{1-42}$
Fig. 5 Congo red staining of amyloid- $\beta$ binding in SK-N-BE cells. SK-N-BE neuronal cells were treated with 27-OH $(1 \mu \mathrm{M}), 7 \beta-\mathrm{OH}(1 \mu \mathrm{M}), 24-\mathrm{OH}(1 \mu \mathrm{m})$ or with cholesterol $(1 \mu \mathrm{m})$ for $48 \mathrm{~h}$ and then with $A \beta_{1-42}(1 \mu \mathrm{m})$ for $8 \mathrm{~h}$. Other cells were treated with $A \beta_{1-42}$ alone for $8 \mathrm{~h}$. Untreated cells were taken as control. $A \beta_{1-42}$ binding to cells was observed by confocal laser microscopy: excitation 488-543 nm and emission $560 \mathrm{~nm}$; lens $20 \times / 0.5$, $3 \times$. Images are from one representative experiment of two performed.

nonenzymatic generation of cholesterol oxidation products, i.e., oxysterols, which, unlike the parent compound, often possess strong pro-inflammatory and toxic effects (Sottero et al., 2009; Vejux \& Lizard, 2009). In addition to ROS-mediated oxidation of free cholesterol, dysregulated activity of cytochrome $\mathrm{P}_{450}-46 \mathrm{~A} 1$ and cytochrome $\mathrm{P}_{450}-27 \mathrm{~A} 1$, which respectively generate $24-\mathrm{OH}$ and $27-\mathrm{OH}$, could contribute to an abnormal accumulation of oxysterols in certain brain areas.

The idea that oxysterols might be the missing link between altered cholesterol metabolism in the brain and AD was first proposed by Björkhem's group having developed a highly reliable method to measure cholesterol oxidation products, they showed that 24-OH may reach quite elevated concentrations in the brain, up to $30 \mu \mathrm{m}$ (Lütjohann et al., 1996). They also demonstrated that $24-\mathrm{OH}$, unlike cholesterol, can cross the bloodbrain barrier from the brain into the circulation (Lütjohann et al., 1996) and that $27-\mathrm{OH}$, the major oxysterol found in human plasma (Brown \& Jessup, 1999), readily flows from the circulation into the brain (Heverin et al., 2005). Further, as regards the potential neurotoxicity of oxysterols, the same team showed that $24-\mathrm{OH}$ caused cell death when added at a $50 \mu \mathrm{m}$ concentration to undifferentiated SH-SY5Y neuronal cells (Kölsch et al., 1999).

In this connection, in brain cortex obtained post mortem from patients with $A D$, selective expression of cytochrome $P_{450}-46 A 1$ (the enzyme that synthesizes 24-OH) was demonstrated in astroglial cells (Bogdanovic et al., 2001) and at the neuritic periphery of amyloid plaques (Brown et al., 2004). The latter finding could be very important despite the fact that the same immunocytochemical method showed a decrease in cortical neurons expressing cytochrome $\mathrm{P}_{450}-46 \mathrm{~A} 1$, likely because of neuronal loss caused by the disease. The number of neurons

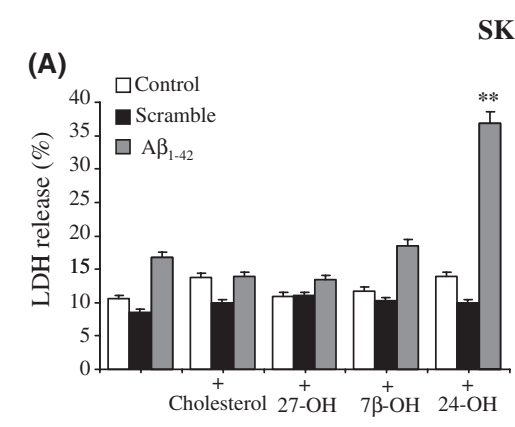

SK-N-BE

(B)
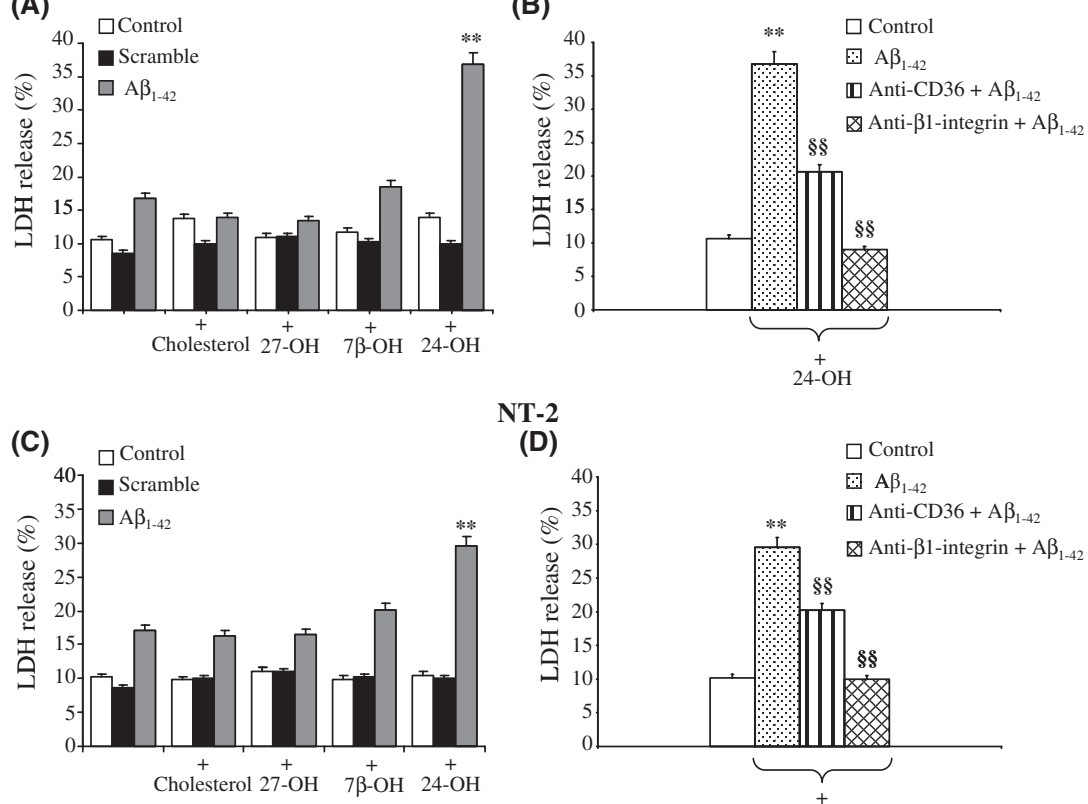

NT-2

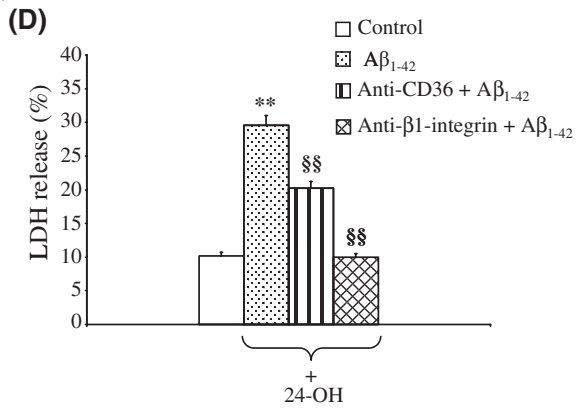

Fig. 6 Effect of 27-hydroxycholesterol (27-OH), 7 $\beta$-hydroxycholesterol (7ß-OH), and 24-hydroxycholesterol (24-OH) on lactate dehydrogenase (LDH) release. SK-N-BE (A) or NT-2 (C) cells were treated with $27-\mathrm{OH}, 7 \beta-\mathrm{OH}$, or $24-\mathrm{OH}$ at the final concentration of $1 \mu \mathrm{m}$ for $48 \mathrm{~h}$ and then for $24 \mathrm{~h}$ with scramble (1 $\mu \mathrm{m}$ ) or A $\beta_{1-}$ ${ }_{42}(1 \mu \mathrm{M})$. Untreated cells were taken as control. Some SK-N-BE (B) or NT-2 (D) cell aliquots were also pre-incubated for $1 \mathrm{~h}$ with anti-CD36 $\left(4 \mu \mathrm{g} \mathrm{mL}{ }^{-1}\right)$ or anti- $\beta 1$ integrin $\left(4 \mu \mathrm{g} \mathrm{mL}{ }^{-1}\right.$ ) antibodies after $24-\mathrm{OH}$ incubation and before adding $A \beta_{1-42}$. Histograms represent the mean values \pm standard deviation of three experiments. ${ }^{*} P<0.01$ vs. control group; $\S \S P<0.01$ vs. $24-\mathrm{OH}+\mathrm{A} \beta_{1-42}$. 
(A)
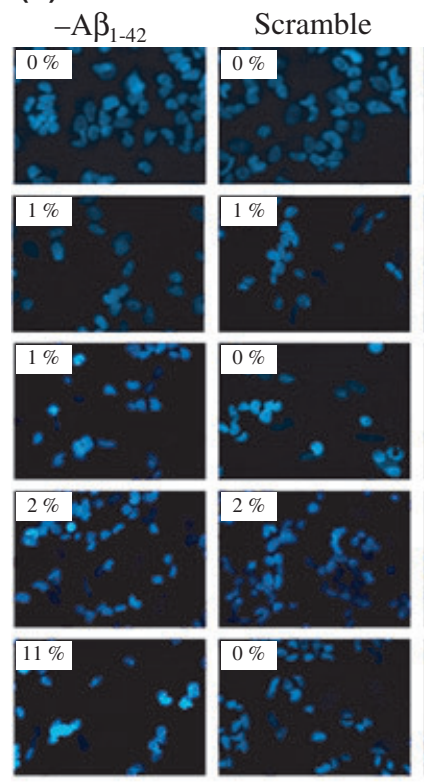

(C)
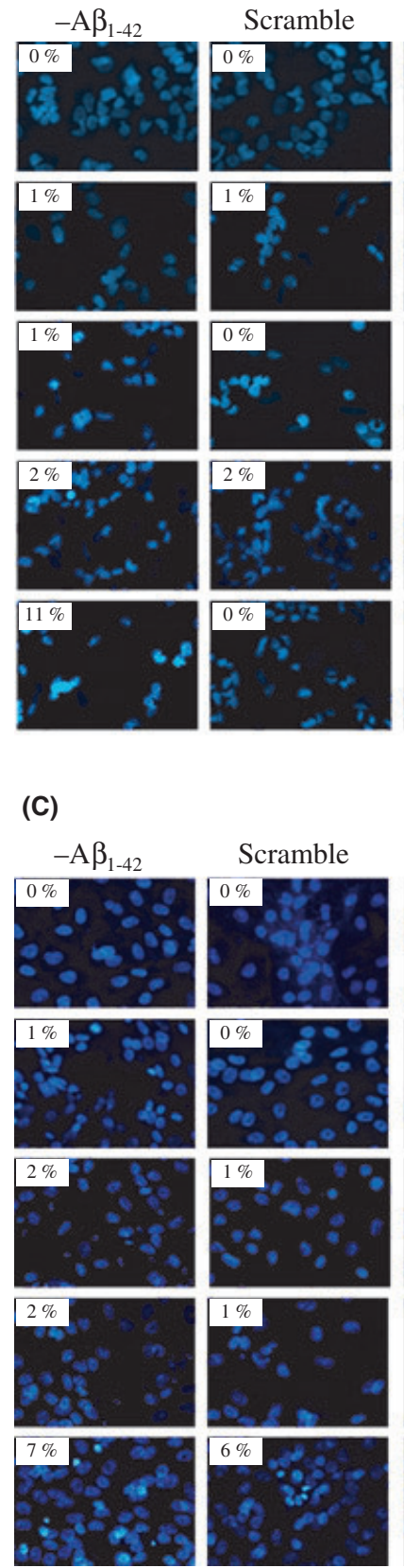
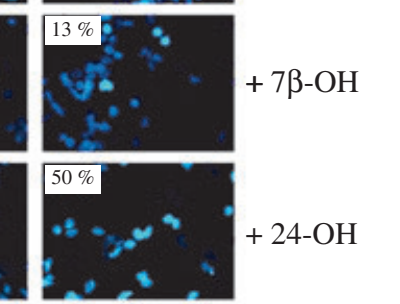

NT-2
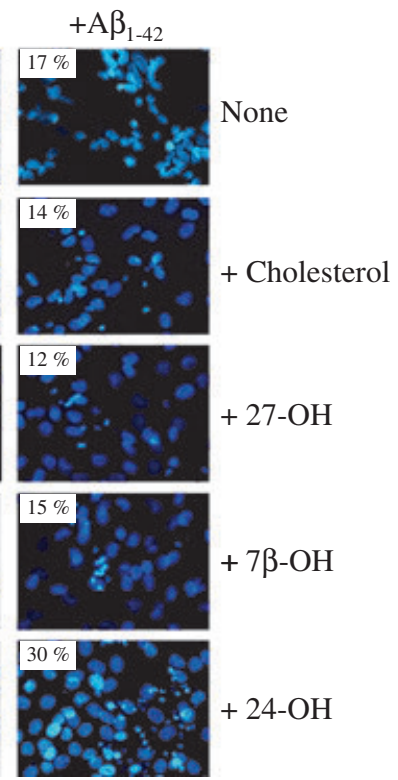

(B)

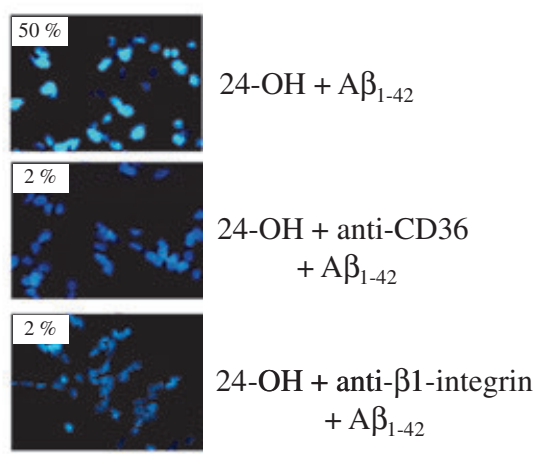

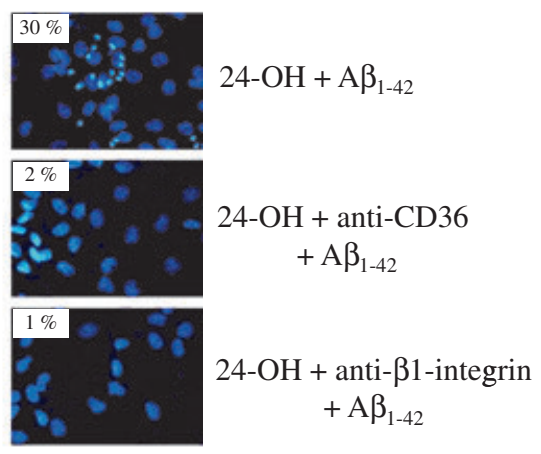

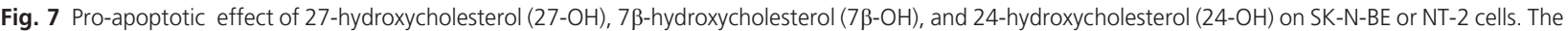
formation of apoptotic nuclei was evaluated in terms of DAPI staining in SK-N-BE (A) or NT-2 (C) cells treated with 27-OH, 7 $\beta-O H$, or 24-OH at a final concentration of $1 \mu \mathrm{m}$ for $48 \mathrm{~h}$ and then for $24 \mathrm{~h}$ with scramble $(1 \mu \mathrm{M})$ or $\mathrm{A} \beta_{1-42}(1 \mu \mathrm{M})$. Some SK-N-BE (B) or NT-2 (D) cell aliquots were also pre-incubated for $1 \mathrm{~h}$ with anti-CD36 $\left(4 \mu \mathrm{g} \mathrm{mL}^{-1}\right)$ or anti- $\beta 1$-integrin $\left(4 \mu \mathrm{g} \mathrm{mL}{ }^{-1}\right)$ antibodies after $24-\mathrm{OH}$ incubation and before adding $A \beta_{1-42}$. The reported percentage of cells with chromatin condensation represents the means of three experiments.

expressing cytochrome $\mathrm{P}_{450}-27 \mathrm{~A} 1$ also appeared to be reduced in the cortical tissue from patients with $A D$ but the enzyme was found to be prominently expressed in white matter oligodendrocytes (Brown et al., 2004). This change in the distribution and net amount of these two enzymes in the brain of patients with $A D$ was confirmed by mass-spectrometric measurement of 24$\mathrm{OH}$ and $27-\mathrm{OH}$ in the autoptic samples of AD subjects; the for- mer oxysterol decreased, while the latter increased in all brain areas examined (Heverin et al., 2004).

Although the actual concentration and distribution of $24-\mathrm{OH}-$ and 27-OH-producing enzymes in AD brains is still debated, the abnormal increase in cytochrome $\mathrm{P}_{450}-46 \mathrm{~A} 1$ in the astrocytes of $A D$ brains (Bogdanovic et al., 2001) and the prominent localization of cytochrome $\mathrm{P}_{450}-46 \mathrm{~A} 1$ around the amyloid plaques 
(A)

\section{SK-N-BE}
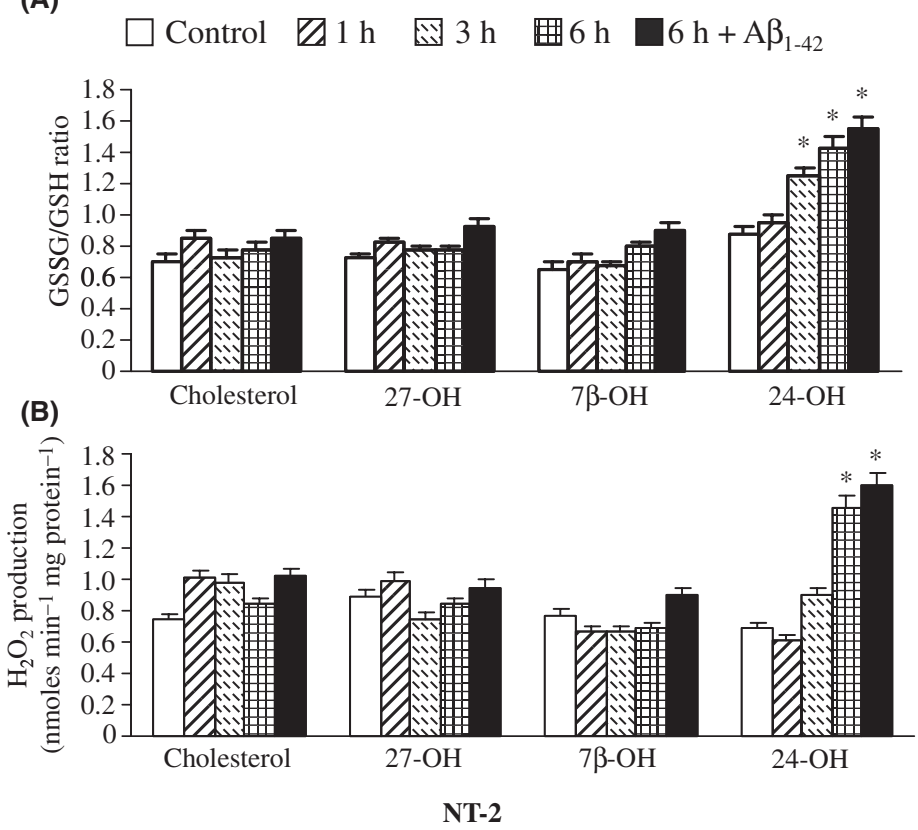

$\square$ Control $\square 1 \mathrm{~h} \quad$ 圈 $3 \mathrm{~h} \quad$ 团 $6 \mathrm{~h}$
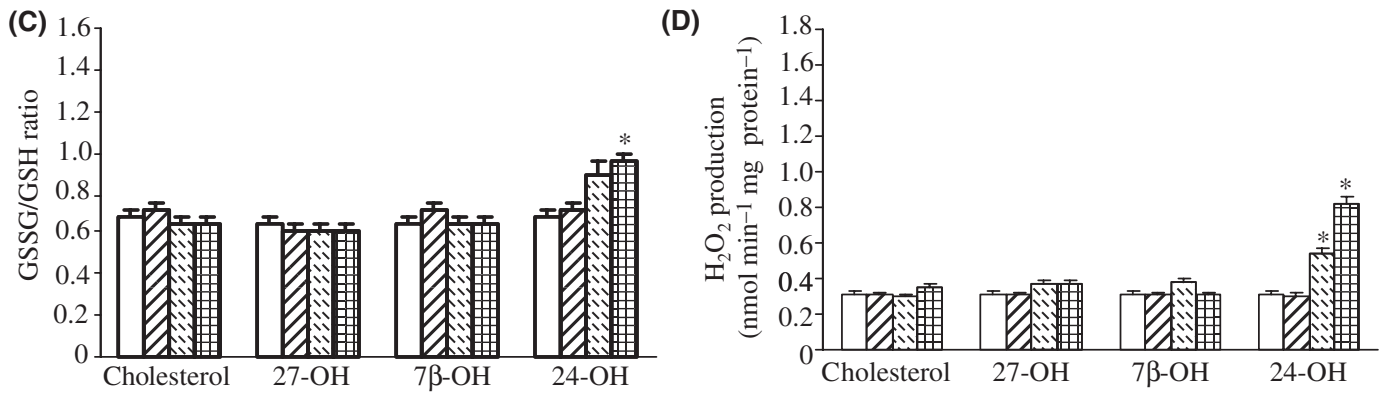

Fig. 8 Effect of 27-hydroxycholesterol (27-OH), 7 $\beta$-hydroxycholesterol (7 $\beta-\mathrm{OH})$, and 24-hydroxycholesterol (24-OH) on GSSG/GSH ratio and on $\mathrm{H}_{2} \mathrm{O}_{2}$ production. GSSG/GSH ratio and $\mathrm{H}_{2} \mathrm{O}_{2}$ production were measured in SK-N-BE (A and B) and NT-2 (C and D) cells after incubation with oxysterols or cholesterol, at a final concentration of $1 \mu \mathrm{M}$, for 1, 3, or $6 \mathrm{~h}$. Untreated cells were taken as control. Other SK-N-BE cells were treated with the oxysterols for $3 \mathrm{~h}$ and then for three additional hours also with $\mathrm{A} \beta_{1-42}(1 \mu \mathrm{m})$. Histograms represent mean values \pm standard deviation of three experiments. ${ }^{*} P<0.05$ vs. control.

(Brown et al., 2004) clearly point to a potential interaction between $24-\mathrm{OH}$ and $\mathrm{A} \beta$ peptides in bringing about neurotoxic effects.

Amyloid- $\beta$ may bind to a number of biomolecules and receptors, the best characterized of which are those mediating the binding to glial cells, namely a multireceptor complex involving CD36, a6ß1-integrin, and CD47 (Bamberger et al., 2003; Verdier et al., 2004). Of interest, binding of the peptide to cell membranes facilitates the formation of amyloid oligomers and fibrils, which are responsible for a series of structural and functional cell changes (Jiang et al., 2009; Sakono \& Zako, 2010). To our knowledge, the present study offers the first report of the enhancement of $A \beta$ binding to neuronal cells exerted by AD-relevant oxysterols. All three of the oxysterols specifically implicated in brain pathophysiology, namely $27-\mathrm{OH}, 7 \beta-\mathrm{OH}$, and 24- $\mathrm{OH}$, have been proved to strongly up-regulate not only
CD36 but also $\beta 1$-integrin expression and synthesis (the specific integrin $\alpha$ subunits involved were not determined) in two different human differentiated neuronal cell lines, SK-N-BE and NT-2 (Figs 1 and 3). In a second part of this research, SK-N-BE neuronal cell pretreatment with either $27-\mathrm{OH}$, or $7 \beta-\mathrm{OH}$, or $24-\mathrm{OH}$, followed by addition of synthetic $A \beta_{1-42}$, strongly increased the amount of the peptide actually bound to cell plasma membranes, vs. oxysterol-untreated cells (Fig. 4). Congo red staining of oxysterol-treated SK-N-BE (Fig. 5) indirectly confirmed the key role of the CD36/ $\beta 1$-integrin/CD47 receptor complex in binding and concentrating the amyloid peptide on the cell surface.

The most interesting finding reported here, however, is the demonstration that even though all three oxysterols of potential relevance in $A D$ pathogenesis may up-regulate the $C D 36 / \beta 1$-integrin binding complex and stimulate $A \beta$ binding 
(A)
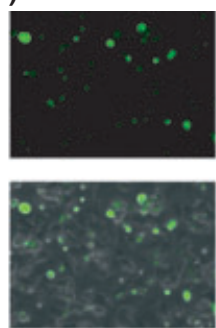

Control
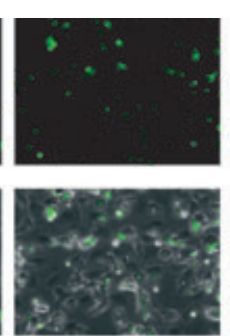

Cholesterol
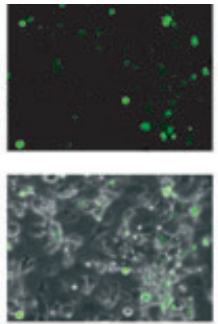

27-OH
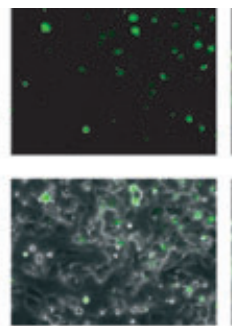

$7 \beta-\mathrm{OH}$
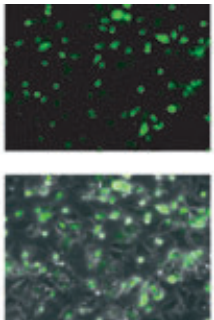

24-OH
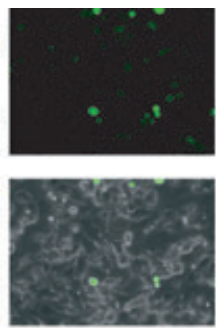

Quercetin $+24-\mathrm{OH}$
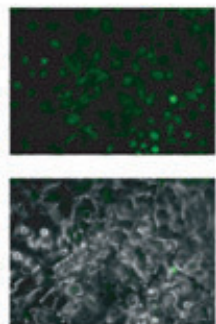

Quercetin

$+24-\mathrm{OH}$

(D)
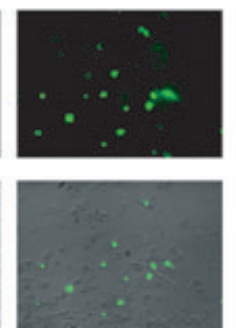

24-OH

$+\mathrm{A} \beta_{1-42}$
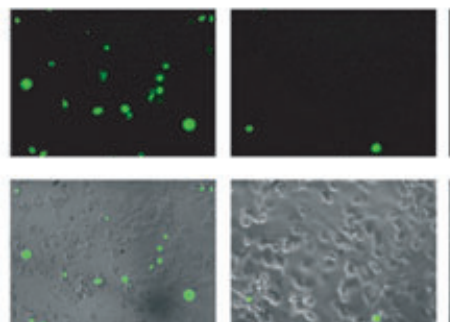

DPI

$+24-\mathrm{OH}$

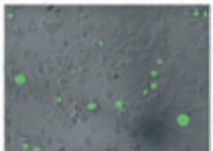

24-OH
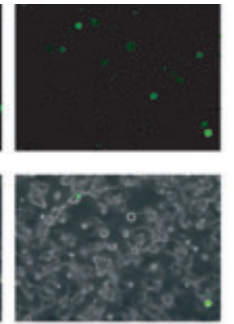

Genistein

$+24-\mathrm{OH}$

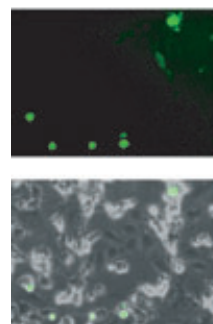

$\mathrm{A} \beta_{1-42}$
$27-\mathrm{OH}$

$+\mathrm{A} \beta_{1-42}$
$7 \beta-\mathrm{OH}$

$+\mathrm{A} \beta_{1-42}$
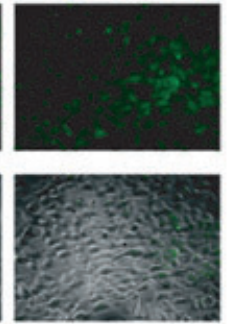

Genistein $+24-\mathrm{OH}$
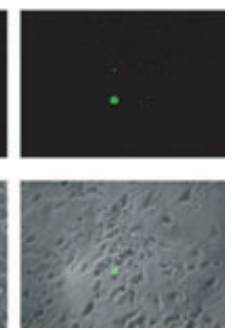

APO

$+24-\mathrm{OH}$

Fig. 9 Pro-oxidant effect of 27-hydroxycholesterol (27-OH), 7 $\beta$-hydroxycholesterol $(7 \beta-\mathrm{OH})$, and 24-hydroxycholesterol (24-OH). Intracellular generation of reactive oxygen species was run with 2'7'-dichlorodihydrofluorescein (DCFH-DA) in SK-N-BE (A,C,D) or NT-2 (B) cells. Cells were incubated with the oxysterols (all at $1 \mu \mathrm{m})$, cholesterol $(1 \mu \mathrm{M})$, or $\mathrm{A} \beta_{1-42}(1 \mu \mathrm{M})$ for $1 \mathrm{~h}$. Defined cell aliquots were simultaneously treated with the oxysterols and with $\mathrm{A} \beta_{1-42}(1 \mu \mathrm{m})$ for $1 \mathrm{~h}$. Untreated cells were taken as control. Other cells were pre-incubated with quercetin ( $5 \mu \mathrm{M})$ or genistein ( $5 \mu \mathrm{M})$ for $1 \mathrm{~h}$ or pre-incubated with diphenyleneiodonium (DPI) $(5 \mu \mathrm{m})$ or apocynin (APO) (300 $\mu \mathrm{m})$ for 30 min and then treated with 24-OH (1 $\mu \mathrm{m})$.

to human neuronal cells, only $24-\mathrm{OH}$ significantly potentiates both the necrogenic and the apoptotic effects exerted by $A \beta_{1-42}$ peptide on these cells (Figs $6 A, C$ and $7 A, C$ ). These effects were inhibited when 24-OH-treated neuronal cells were incubated with anti-CD36 and anti- $\beta 1$-integrin antibodies before $A \beta_{1-42}$ addition because $A \beta$ peptide binding to cell surface was prevented (Figs $6 B, D$ and $7 B, D$ ). A study by Ferrera et al. (2008) showed that treatment of the human differentiated neuroblastoma cell line MSN with $A \beta_{1-42}$ peptide moderately impaired the mitochondrial reducing capacity, leading to about a $20 \%$ decrease in cell viability. Addition of a relatively high concentration $(50 \mu \mathrm{m})$ of either cholesterol or $24-\mathrm{OH}$ further increased, by about $10 \%$, the toxic effect of the $A \beta$ peptide. Data reported here are consistent with that study, but refer to the effect of $1 \mu \mathrm{M} 24$ -
$\mathrm{OH}$, and show much stronger potentiation of $\mathrm{A} \beta$ toxicity by the oxysterol, as well as demonstrating it in greater detail. In addition, the Ferrera study reported increased ROS generation induced in MSN cells by supplementation with $50 \mu \mathrm{M}$ cholesterol (Ferrera et al., 2008) and considered this finding to be the consequence of the already established generation of $\mathrm{H}_{2} \mathrm{O}_{2}$ by amyloid- $\beta$ in the presence of cholesterol as reducing agent (Opazo et al., 2002). Notably, they did not directly check whether $24-\mathrm{OH}$ exerted a pro-oxidant effect in their model system.

At least one significant reason for the selective neurotoxic behavior of $24-\mathrm{OH}$ reported here appears to be the marked prooxidant action on neuronal cells that this compound, but not $27-$ $\mathrm{OH}$ nor $7 \beta-\mathrm{OH}$, exerts at relatively low concentrations (1 $\mu \mathrm{m})$ (Figs 8 and 9). The addition of $A \beta_{1-42}$ to oxysterol-treated SK-N- 

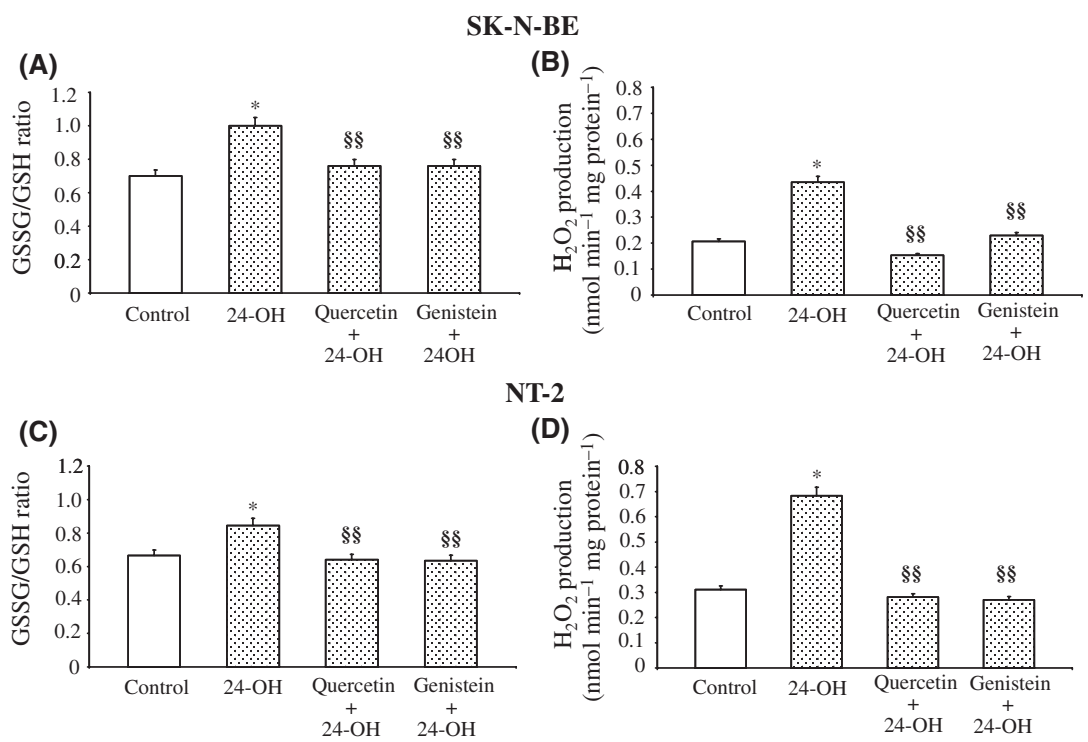

Fig. 10 Protection exerted by antioxidants quercetin and genistein on GSSG/GSH ratio and on $\mathrm{H}_{2} \mathrm{O}_{2}$ production. GSSG/GSH ratio and $\mathrm{H}_{2} \mathrm{O}_{2}$ production were measured in SK-N-BE (A and B) and NT-2 (C and D) cells after incubation with $1 \mu \mathrm{m} 24-\mathrm{OH}$ for $6 \mathrm{~h}$. Untreated cells were taken as control. Other cells were preincubated with quercetin $(5 \mu \mathrm{M})$ or genistein $(5 \mu \mathrm{M})$ for $1 \mathrm{~h}$ and then treated with $24-\mathrm{OH}(1 \mu \mathrm{M})$ for 6 h. Histograms represent the mean values \pm standard deviation of three experiments. ${ }^{*} P<0.05$ vs. control; $\S \S P<0.01$ vs. $24-\mathrm{OH}$ alone.
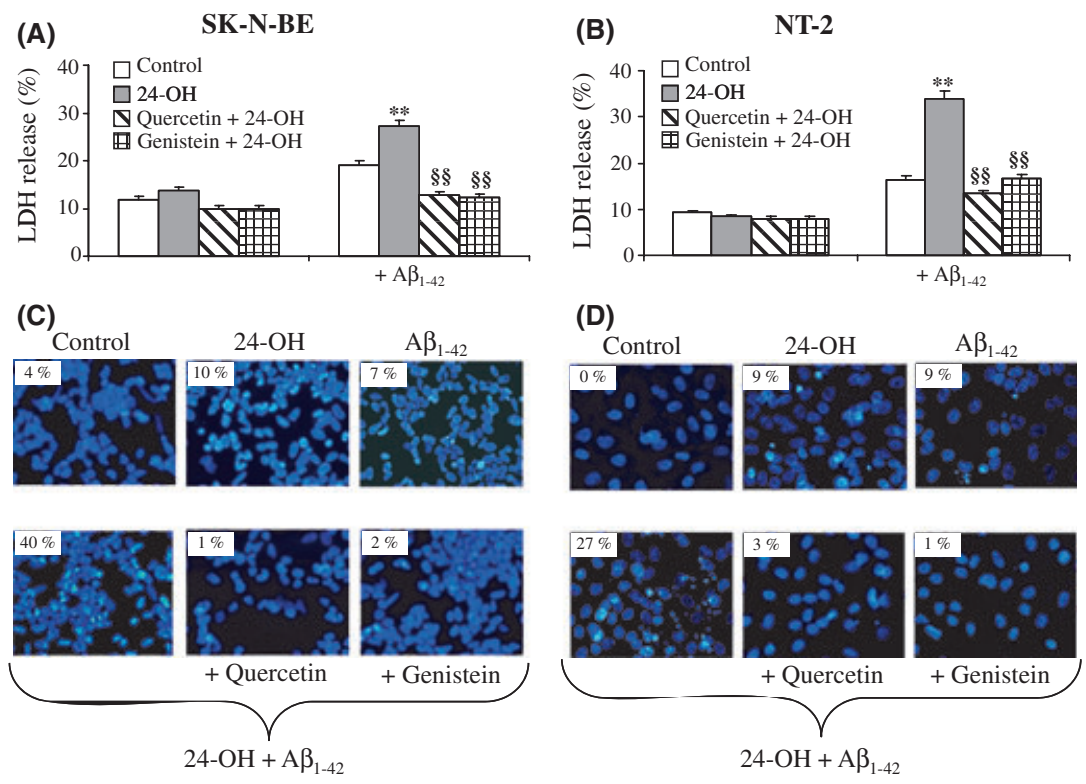

Fig. 11 Protection exerted by antioxidants quercetin or genistein on lactate dehydrogenase (LDH) release as well as on apoptotic nuclei formation. Lactate dehydrogenase release and the formation of apoptotic nuclei were analyzed in SK-N-BE (A and C) or NT-2 (B and D) cells. Cells were incubated with $1 \mu \mathrm{m} 24-\mathrm{OH}$ for $48 \mathrm{~h}$ and then with or without $1 \mu \mathrm{m} A \beta_{1-42}$ for $24 \mathrm{~h}$. Untreated cells were taken as control. Other cells were incubated with $A \beta_{1-42}$ alone $(1 \mu \mathrm{m})$ for $24 \mathrm{~h}$ and others were pre-incubated with quercetin $(5 \mu \mathrm{m})$ or genistein $(5 \mu \mathrm{m})$ for $1 \mathrm{~h}$ and then treated with $24-\mathrm{OH}(1 \mu \mathrm{m})$ for $48 \mathrm{~h}$ and with $\mathrm{A} \beta_{1-42}(1 \mu \mathrm{m})$ for $24 \mathrm{~h}$. Histograms represent mean values \pm standard deviation of three experiments. ${ }^{*} P<0.01$ vs. control group; $\S \S P<0.01 \mathrm{vs}$. $24-\mathrm{OH}+\mathrm{A} \beta_{1-42}$. The reported percentage of cells with chromatin condensation represents the means of three experiments.

BE neuronal cells did not modify the pro-oxidant effect of the three oxysterols (Figs 8A,B and 9C). 24-OH-dependent potentiation of $A \beta$ neurotoxicity was completely inhibited by incubation of differentiated SK-N-BE or NT-2 cells with either the flavonol quercetin or the isoflavone genistein (Fig. 11), both of which efficiently prevented ROS over-production and GSSG/GSH imbalance induced by 24-OH (Figs 9 and 10). Fully consistent with these data is the previous report of significant quenching of 24-OH's pro-apoptotic effect by physiologic concentrations of vitamin $\mathrm{E}$ in differentiated human neuronal cells SH-SY5Y (Kölsch et al., 
2001). However, antioxidant molecules such as quercetin and genistein appear by far more promising, because they can cross the blood-brain barrier thank to their polyphenolic hydroxyl groups (Sarkar \& Das, 2006; Jakóbkiewicz-Banecka et al., 2007).

In conclusion, the $24-\mathrm{OH}$ produced by cytochrome $\mathrm{P}_{450}-46 \mathrm{~A} 1$ in the close vicinity of amyloid plaques appears to strongly enhance the adhesion of large amounts of $A \beta$ to the plasma membrane of neurons and then to amplify the neurotoxic action of the peptide by locally increasing ROS (mainly $\mathrm{H}_{2} \mathrm{O}_{2}$ ) steadystate levels.

Oxidative stress is now generally recognized as one of the earlier changes in $A D$, and it is considered to be a main driving force in its early promotion and progression (Odetti et al., 1998; Perry et al., 1998; Nunomura et al., 2001; Cutler et al., 2004; Zhu et al., 2007b; Smith et al., 2010). In relation to this, numerous studies carried out on animal models have demonstrated the ability of dietary docosahexaenoic acid supplementation to modulate amyloid pathology by preserving neuronal and brain functions: among the mechanisms involved, the anti-oxidant and anti-inflammatory properties of the $n-3$ fatty acid likely play a primary role (Oster \& Pillot, 2010).

There are various sources of ROS in $A D$, including abnorma mitochondria, redox active iron and copper, activated glial cells, lipid peroxidation, and glycation end-products (Zhu et al., 2007a). The here reported inhibition by NADPH oxidase inhibitors of 24-OH-induced neuronal ROS levels points to this enzyme as an additional and primary source of oxidant species (Fig. 9D). However, the mechanisms underlying the action of ROS in AD are still under investigation. The ROS-mediated neurotoxic interaction between $24-\mathrm{OH}$ and $\mathrm{A} \beta$ might be one such mechanism, and at least the aliquot of $24-\mathrm{OH}$ localized at senile plaques should probably be added to the list of ROS sources in $A D$. Future studies should cast further light on the possible modulation of neurotoxicity because of the triad $24-\mathrm{OH}$-oxidative stress- $A \beta$, by the simultaneous presence of $27-\mathrm{OH}$ and other oxysterols, by astrocytes and microglial cells, by redox active metals, and, last but not least, by anti-inflammatory drugs and antioxidants that can cross the blood-brain barrier.

The obtained findings support the therapeutic use of statins in lowering the risk of dementia, not only because of their cholesterol-lowering, antioxidant, and anti-inflammatory effects but also because of their proved lowering effect on plasma oxysterols, including 24-OH (Locatelli et al., 2002; Vega et al., 2003).

\section{Experimental procedures}

\section{Cell culture and differentiation}

SK-N-BE neuroblastoma cells were grown in Roswell Park Memorial Institute (RPMI) 1640 medium containing 2 mm glutamine and supplemented with $10 \%$ fetal bovine serum, $1 \%$ antibiotic mixture (penicillin-streptomycin-amphotericin). NT-2 neuronal cells were grown in Dulbecco's modified Eagle's medium (DMEM), supplemented with 10\% fetal bovine serum and $1 \%$ antibiotic mixture, comprising penicillin-streptomycin- amphotericin. Both cell lines were maintained in a humidified atmosphere at $37^{\circ} \mathrm{C}$ with $5 \% \quad \mathrm{CO}_{2}$. For differentiation, $2 \times 10^{6}$ cells were plated in $75-\mathrm{cm}^{2}$ flasks (Costar, Lowell, MA, USA) and exposed to $10 \mu \mathrm{m}$ retinoic acid for 10 days in the case of SK-N-BE cells and for 5 weeks for NT-2 cells. Growth medium was changed three times a week for both cell lines. After 5 weeks of differentiation of NT-2 cells, the mitotic inhibitors cytosine arabinoside (1 $\mu \mathrm{m})$, fluorodeoxyuridine (10 $\mu \mathrm{m})$, and uridine $(10 \mu \mathrm{M})$ were added for 2 weeks to inhibit the division of non-neuronal cells.

\section{Cell treatments}

Cells were treated with $1 \mu \mathrm{M}$ 27-hydroxycholesterol (27-OH), $1 \mu \mathrm{M} 7 \beta$-hydroxycholesterol (7 $\beta-\mathrm{OH}), 1 \mu \mathrm{m}$ 24-hydroxycholesterol (24-OH), or $1 \mu \mathrm{m}$ unoxidized cholesterol (Steraloids, Newport, RI, USA), all dissolved in ethanol. Some oxysterol-treated cells were then treated with $A \beta_{1-42}(1 \mu \mathrm{M})$ (Bachem, Bubendorf, Switzerland) or with scramble $A \beta(1 \mu \mathrm{M})$ (AnaSpec, Fremont, CA, USA). Fresh $A \beta_{1-42}$ peptide stock solutions were prepared at $1 \mathrm{mg} \mathrm{mL}^{-1}$ in hexafluoro-2-isopropanol (Sigma-Aldrich, Milan, Italy), quickly dried under nitrogen, and directly solubilized at the experimental concentration in the culture medium. In certain experiments, cells were pretreated with anti-CD36 antibody (2 or $4 \mu \mathrm{g} \mathrm{mL}^{-1}$ ) (Clone FA6-152; HyCult Biotechnology b.v., Uden, the Netherlands) or with anti- $\beta 1$-integrin antibody ( 2 or $4 \mu \mathrm{g} \mathrm{mL}^{-1}$ ) (Clone 4B7R; Santa Cruz, Biotechnology Inc., Santa Cruz, CA, USA) and others were pretreated with quercetin $(5 \mu \mathrm{m})$ (Sigma-Aldrich) or genistein $(5 \mu \mathrm{m})$ (Alexis Biochemicals, Lausen, Switzerland) and with diphenyleneiodonium $(5 \mu \mathrm{m})$ or apocynin $(300 \mu \mathrm{m})$ (Sigma-Aldrich), two NADPH oxidase inhibitors. Incubation times for all experiments are reported in the Results section and Figure legends.

\section{RNA extraction}

Total RNA was extracted from cells using TRIzol Reagent (Applied Biosystems, Monza, Italy) following the manufacturer's instructions after the treatment times indicated. RNA was dissolved in RNase-free water fortified with RNase inhibitors (RNase SUPERase-In; Ambion, Austin, TX, USA). The amount and purity (A260/A280 ratio) of the extracted RNA were assessed spectrophotometrically.

\section{CDNA preparation and real-time RT-PCR}

CDNA was synthesized by reverse transcription from $2 \mu \mathrm{g}$ RNA with a commercial kit and random primers (High-Capacity CDNA Reverse Transcription Kit; Applied Biosystems) following the manufacturer's instructions. Singleplex real-time RT-PCR was performed on $30 \mathrm{ng}$ of cDNA using TaqMan Gene Expression Assay kits prepared for human CD36, $\beta 1$-integrin, CD47, and $\beta_{2}$-microglobulin, TaqMan Fast Universal PCR Master Mix, and 7500 Fast Real-Time PCR System (Applied Biosystems). Negative controls did not include cDNA. The oligonucleotide sequences 
are not revealed by the manufacturer because of proprietary interests. The cycling parameters were as follows: $20 \mathrm{~s}$ at $95^{\circ} \mathrm{C}$ for AmpErase UNG activation, $3 \mathrm{~s}$ at $95^{\circ} \mathrm{C}$ for AmpliTaq Gold DNA polymerase activation, 40 cycles of $3 \mathrm{~s}$ at $95^{\circ} \mathrm{C}$ (melting), and $30 \mathrm{~s}$ at $60^{\circ} \mathrm{C}$ (annealing/extension). The fractional cycle number $(\mathrm{Ct})$ at which fluorescence passes the threshold in the amplification plot of fluorescence signal vs. cycle number was determined for each gene considered. The results were then normalized to the expression of $\beta_{2}$-microglobulin, as housekeeping gene. Relative quantification of target gene expression was achieved with a mathematical method proposed by Livak \& Schmittgen (2001).

\section{Western blotting}

Whole-cell extracts were prepared in ice-cold lysing buffer $(1 \mathrm{~mL}$ of phosphate-buffered saline (PBS) was added with $10 \mu \mathrm{L}$ Triton X-100, $10 \mu \mathrm{L}$ SDS 10\%, $5 \mu \mathrm{L}$ DTT $1 \mathrm{M}, 6 \mu \mathrm{L}$ PMSF $0.1 \%, 10 \mu \mathrm{L}$ aprotinin) for $30 \mathrm{~min}$ and sonicated for $20 \mathrm{~s}$. The lysates were then cleared by centrifugation at $17860 \mathrm{~g}$ for $15 \mathrm{~min}$. The protein concentration was measured following Bradford's method (Bradford, 1976).

To analyze the levels of CD36 and $\beta 1$-integrin, $100 \mu \mathrm{g}$ of total proteins were immunoprecipitated, respectively, with $8 \mu \mathrm{L}$ of anti-CD36 primary antibody (Santa Cruz Biotechnology Inc., Santa Cruz, CA, USA) or with $8 \mu \mathrm{L}$ of anti- $\beta 1$-integrin primary antibody (Santa Cruz Biotechnology Inc.), purified on Protein A Sepharose resin (GE Healthcare Europe, Milan, Italy), boiled in Laemmli buffer for $5 \mathrm{~min}$, separated by electrophoresis in $8 \%$ denaturing SDS/polyacrylamide gel, and then electroblotted onto Hybond ECL nitrocellulose membrane (GE Healthcare Europe). For CD36 and $\beta 1$-integrin level analysis, after saturation of nonspecific binding sites with $5 \%$ nonfat milk in Tris-buffered saline (TBS) 1 x-Tween 20 0.05\%, membranes were immunoblotted overnight at $4{ }^{\circ} \mathrm{C}$ with the appropriate primary antibody against CD36 (1:150) or $\beta 1$-integrin (1:150) (Santa Cruz Biotechnology Inc.), both diluted in 5\% nonfat milk in TBS $1 \times$-Tween $200.05 \%$ and subsequently probed with an antimouse secondary antibody (1:1000) (Santa Cruz Biotechnology Inc.) for $3 \mathrm{~h}$ at room temperature.

The supernatants obtained after CD36 and $\beta 1$-integrin immunoprecipitation were again immunoprecipitated with $5 \mu \mathrm{L}$ of anti-actin primary antibody (Sigma-Aldrich). Proteins were separated by electrophoresis in $8 \%$ denaturing SDS/polyacrylamide gels, electroblotted onto nitrocellulose membranes, and incubated with anti-actin primary antibody (1:10 000) and then with anti-rabbit secondary antibodies (1:7500) (Santa Cruz Biotechnology Inc.), as described earlier. Proteins detected by the antibodies were visualized by enhanced chemiluminescence using the ECL-plus kit (GE Healthcare Europe) following the manufacturer's directions. The immunoreactive bands were scanned and subjected to densitometric analysis using 'Image Tool' software (Windows 3.00). The results were evaluated as relative units determined by normalization of the density of each band to that of the corresponding actin protein band.

\section{Analysis of $A \beta_{1-42}$ by confocal laser microscopy}

Cells were grown on glass slides and, after the treatment times, specimens were fixed in $4 \%$ formalin for 15 min at room temperature. They were then washed $(0.1 \mathrm{M}$ PBS) and incubated with a $100 \mathrm{~mm}$ sodium cyanoborohydride reducing agent for $10 \mathrm{~min}$ at $37^{\circ} \mathrm{C}$. To block nonspecific binding, cells were incubated with $3 \%$ BSA in $0.01 \mathrm{~m}$ PBS containing 5\% goat serum and $0.3 \%$ Tween 20, for 30 min at room temperature. After blocking nonspecific binding, slides were incubated in the presence of antibodies to human $A \beta_{1-42}$ (1:500) (Bachem) and then with purified goat antimouse fluorescein isothiocyanate (FITC) fluorochrome-conjugated secondary antibodies (1:300) (Alexa Fluor 488; Molecular Probes-Invitrogen Srl, San Giuliano, Milanese, Italy). Slides mounted with glycerol/distilled water (1:1) plus $0.1 \% \mathrm{NaN}_{3}$ were observed through the LSM 510 confocal laser microscope (Carl Zeiss SpA, Arese, Milan, Italy) equipped with an inverted microscope with Plan-NEOFLUAR lenses $(40 \times / 0.75)$.

\section{Congo red staining}

Cells were grown on glass slides and, after the treatment times, specimens were fixed in $4 \%$ formalin for $15 \mathrm{~min}$ at room temperature. SK-N-BE neuroblastoma cells were washed with $0.1 \mathrm{~m}$ PBS and then dipped into Harris hematoxylin for 3 min. After washing with tap water, specimens were stained with a fresh solution of $0.5 \%$ filtered Congo red (Sigma-Aldrich) at room temperature for $3 \mathrm{~min}$. After several washes with deionized water, specimens were dehydrated in increasing alcohol solutions (50\%, 70\%, $80 \%, 95 \%$, and 100\%) and cleared with xylene. Slides mounted in DPX (Sigma-Aldrich) were observed with a LSM 510 confocal laser microscopy system (Carl Zeiss SpA).

\section{Preparation of cell lysates and cytosolic fraction}

Confluent differentiated cells were treated under the appropriate experimental conditions and placed immediately on ice-cold PBS. Cell lysates and cytosolic extracts were obtained by the method of Andrews \& Faller (1991).

\section{Analysis of cell death}

Lactate dehydrogenase (LDH) activity was determined in culture medium using a photometric assay based on the conversion of pyruvic acid to lactic acid by the enzyme, as described elsewhere (Tamagno et al., 2000). Values for control and treated cells were expressed as percentages of the total LDH activity released by untreated cells, which were lysed with Triton X100.

The rate of apoptosis was evaluated through 4',6'-diamidino2-phenylindole (DAPI) staining. To identify apoptotic nuclei, cells were washed in PBS, fixed and permeabilized with 95\% cold ethanol for $5 \mathrm{~min}$, and then stained with DAPI solution for 30 min at $37^{\circ} \mathrm{C}$. After rinsing in PBS, cells were observed and photographed under a Zeiss fluorescence microscope. 


\section{Oxidative stress determinations}

Intracellular generation of ROS was detected through the conversion of $2^{\prime}, 7^{\prime}$-dichlorofluorescein diacetate (used at $5 \mu \mathrm{m}$ concentration), once taken up by cells and de-acetylated by esterase, into the corresponding fluorescent derivative (Rezvani et al., 2007). Cells were observed and photographed under a Zeiss fluorescence microscope. The amount of ROS was expressed as percentage of fluorescent cells.

Antioxidant levels in the cytosolic fractions were evaluated in terms of the GSSG/GSH ratio, by the Owens \& Belcher (1965) method. A mixture was directly prepared in a cuvette: $0.05 \mathrm{~mm}$ Na phosphate buffer, pH 7.0; 1 mM EDTA, pH 7.0; and 10 mm $5,-5^{\prime}$-dithiobis-(2-nitrobenzoic acid) plus an aliquot of the sample. Total thiol content was evaluated after 2 min at $412 \mathrm{~nm}$ and expressed as $\mu \mathrm{g} / \mathrm{mg}$ protein. Suitable volumes of diluted GSH reductase and of NADPH were added to evaluate total GSH. The ratio between GSSG and GSH content is considered to be a measure of antioxidant status.

Generation of $\mathrm{H}_{2} \mathrm{O}_{2}$ was monitored after adding horseradish peroxidase and acetylated ferrocytochrome $\mathrm{C}$ to cells. $\mathrm{H}_{2} \mathrm{O}_{2}$ content was evaluated as the increase in acetylated ferrocytochrome C oxidation rate as described by Zoccarato et al. (1993).

\section{Statistical analysis}

All values are expressed as means \pm standard deviation (SD). Statistical analysis of the data was assessed using one-way ANOVA with Bonferroni's post-test for multiple comparisons. Differences at $P<0.05$ were considered statistically significant. Statistical calculations were made with GRAPHPAD INSTAT3 software (GraphPad Software Inc., San Diego, CA, USA).

\section{Acknowledgements}

The authors thank the European Science Foundation COST B35 Action, the Italian Ministry of University, Prin 2007 and 2008, the Piedmontese Regional Government (Ricerca Sanitaria Finalizzata 2008, 2008 II, 2009), the CRT Foundation, Turin, and the University of Turin, Italy, for supporting this work.

\section{References}

Andrews NC, Faller DV (1991) A rapid micropreparation technique for extraction of DNA-binding proteins from limiting numbers of mammalian cells. Nucleic Acids Res. 19, 2499.

Bamberger ME, Harris ME, McDonald DR, Husemann J, Landreth GE (2003) A cell surface receptor complex for fibrillar beta-amyloid mediates microglial activation. J. Neurosci. 23, 2665-2674.

Björkhem I (2006) Crossing the barrier: oxysterols as cholesterol transporters and metabolic modulators in the brain. J. Intern. Med. 260, 493-508.

Björkhem I, Meaney S (2004) Brain cholesterol: long secret life behind a barrier. Arterioscler. Thromb. Vasc. Biol. 24, 806-815.
Bogdanovic N, Bretillon L, Lund EG, Diczfalusy U, Lannfelt L, Winblad B, Russell DW, Björkhem I (2001) On the turnover of brain cholesterol in patients with Alzheimer's disease. Abnormal induction of the cholesterol-catabolic enzyme CYP46 in glial cells. Neurosci. Lett. 314, 45-48.

Bonda DJ, Wang X, Perry G, Nunomura A, Tabaton M, Zhu X, Smith MA (2010) Oxidative stress in Alzheimer disease: a possibility for prevention. Neuropharmacology 59, 290-294.

Bradford MM (1976) A rapid and sensitive method for the quantitation of microgram quantities of protein utilizing the principle of protein-dye binding. Anal. Biochem. 72, 248-254.

Brown AJ, Jessup W (1999) Oxysterols and atherosclerosis. Atherosclerosis $142,1-28$.

Brown J 3rd, Theisler C, Silberman S, Magnuson D, Gottardi-Littell N, Lee JM, Yager D, Crowley J, Sambamurti K, Rahman MM, Reiss AB, Eckman CB, Wolozin B (2004) Differential expression of cholesterol hydroxylases in Alzheimer's disease. J. Biol. Chem. 279, 3467434681.

Corder EH, Saunders AM, Strittmatter WJ, Schmechel DE, Gaskell PC, Small GW, Roses AD, Haines JL, Pericak-Vance MA (1993) Gene dose of apolipoprotein E type 4 allele and the risk of Alzheimer's disease in late onset families. Science 261, 921-923.

Cutler RG, Kelly J, Storie K, Pedersen WA, Tammara A, Hatanpaa K, Troncoso JC, Mattson MP (2004) Involvement of oxidative stressinduced abnormalities in ceramide and cholesterol metabolism in brain aging and Alzheimer's disease. Proc. Natl Acad. Sci. USA 101, 2070-2075.

Evans RM, Hui S, Perkins A, Lahiri DK, Poirier J, Farlow MR (2004) Cholesterol and APOE genotype interact to influence Alzheimer disease progression. Neurology 62, 1879-1881.

Ferrera P, Mercado-Gómez O, Silva-Aguilar M, Valverde M, Arias C (2008) Cholesterol potentiates beta-amyloid-induced toxicity in human neuroblastoma cells: involvement of oxidative stress. Neurochem. Res. 33, 1509-1517.

Hashimoto M, Rockenstein E, Crews L, Masliah E (2003) Role of protein aggregation in mitochondrial dysfunction and neurodegeneration in Alzheimer's and Parkinson's diseases. Neuromolecular Med. 4, 21-36.

Heverin M, Bogdanovic N, Lütjohann D, Bayer T, Pikuleva I, Bretillon L, Diczfalusy U, Winblad B, Björkhem I (2004) Changes in the levels of cerebral and extracerebral sterols in the brain of patients with Alzheimer's disease. J. Lipid Res. 45, 185-193.

Heverin M, Meaney S, Lütjohann D, Diczfalusy U, Wahren J, Björkhem I (2005) Crossing the barrier: net flux of 27-hydroxycholesterol into the human brain. J. Lipid Res. 46, 1047-1052.

Jakóbkiewicz-Banecka J, Wêgrzyn A, Wêgrzyn G (2007) Substrate deprivation therapy: a new hope for patients suffering from neuronopathic forms of inherited lysosomal storage diseases. J. Appl. Genet. 48, 383-388.

Jiang $D$, Dinh $K L$, Ruthenburg TC, Zhang $Y$, Su L, Land DP, Zhou F (2009) A kinetic model for beta-amyloid adsorption at the air/solution interface and its implication to the beta-amyloid aggregation process. J. Phys. Chem. B 113, 3160-3168.

Jick H, Zornberg GL, Jick SS, Seshadri S, Drachman DA (2000) Statins and the risk of dementia. Lancet 356, 1627-1631.

Kandiah N, Feldman HH (2009) Therapeutic potential of statins in Alzheimer's disease. J. Neurosci. 283, 230-234.

Kölsch H, Lütjohann D, Tulke A, Björkhem I, Rao ML (1999) The neurotoxic effect of 24-hydroxycholesterol on SH-SY5Y human neuroblastoma cells. Brain Res. 818, 171-175.

Kölsch H, Ludwig M, Lütjohann D, Rao ML (2001) Neurotoxicity of 24hydroxycholesterol, an important cholesterol elimination product of 
the brain, may be prevented by vitamin $\mathrm{E}$ and estradiol-17beta. J. Neural. Transm. 108, 475-488.

Leonarduzzi G, Sottero B, Poli G (2002) Oxidized products of cholesterol: dietary and metabolic origin, and proatherosclerotic effects. J. Nutr. Biochem. 13, 700-710.

Leonarduzzi G, Gamba P, Gargiulo S, Sottero B, Kadl A, Biasi F, Chiarpotto E, Leitinger N, Vendemiale G, Serviddio G, Poli G (2008) Oxidation as a crucial reaction for cholesterol to induce tissue degeneration: CD36 overexpression in human promonocytic cells treated with a biologically relevant oxysterol mixture. Aging Cell 7, 375-382.

Livak KJ, Schmittgen TD (2001) Analysis of relative gene expression data using real-time quantitative PCR and the 2(-Delta Delta $C(T)$ ) method. Methods 25, 402-408.

Locatelli S, Lütjohann D, Schmidt HH-J, Otto C, Beisiegel U, von Bergmann K (2002) Reduction of plasma 24S-hydroxycholesterol (cerebrosterol) levels using high-dosage simvastatin in patients with hypercholesterolemia. Arch. Neurol. 59, 213-216.

Lütjohann D, Breuer O, Ahlborg G, Nennesmo I, Sidén A, Diczfalusy U, Björkhem I (1996) Cholesterol homeostasis in human brain: evidence for an age-dependent flux of 24S-hydroxycholesterol from the brain into the circulation. Proc. Natl Acad. Sci. USA 93, 97999804.

Nelson TJ, Alkon DL (2005) Oxidation of cholesterol by amyloid precursor protein and beta-amyloid peptide. J. Biol. Chem. 280, 73777387.

Nunomura A, Perry G, Aliev G, Hirai K, Takeda A, Balraj EK, Jones PK, Ghanbari H, Wataya T, Shimohama S, Chiba S, Atwood CS, Petersen RB, Smith MA (2001) Oxidative damage is the earliest event in Alzheimer disease. J. Neuropathol. Exp. Neurol. 60, 759-767.

Odetti P, Angelini G, Dapino D, Zaccheo D, Garibaldi S, Dagna-Bricarelli F, Piombo G, Perry G, Smith M, Traverso N, Tabaton M (1998) Early glycoxidation damage in brains from Down's syndrome. Biochem. Biophys. Res. Commun. 243, 849-851.

Opazo C, Huang X, Cherny RA, Moir RD, Roher AE, White AR, Cappai R, Masters CL, Tanzi RE, Inestrosa NC, Bush Al (2002) Metalloenzyme-like activity of Alzheimer's disease beta-amyloid. Cu-dependent catalytic conversion of dopamine, cholesterol, and biological reducing agents to neurotoxic $\mathrm{H}(2) \mathrm{O}(2)$. J. Biol. Chem. 277, 4030240308.

Oster T, Pillot T (2010) Docosahexaenoic acid and synaptic protection in Alzheimer's disease mice. Biochim. Biophys. Acta 1801, 791798.

Owens CW, Belcher RV (1965) A colorimetric micro-method for the determination of Glutathione. Biochem. J. 94, 705-711.

Panza F, Capurso C, D'Introno A, Colacicco AM, De Candia D, Capurso A, Solfrizzi V (2007) Total cholesterol levels and the risk of mild cognitive impairment and Alzheimer's disease. J. Am. Geriatr. Soc. 55, 133-135.

Perry G, Castellani RJ, Hirai K, Smith MA (1998) Reactive oxygen species mediate cellular damage in Alzheimer Disease. J. Alzheimers Dis. 1, 45-55.

Poli G, Sottero B, Gargiulo S, Leonarduzzi G (2009) Cholesterol oxidation products in the vascular remodeling due to atherosclerosis. Mol. Aspects Med. 30, 180-189.

Puglielli L, Tanzi RE, Kovacs DM (2003) Alzheimer's disease: the cholesterol connection. Nat. Neurosci. 6, 345-351.
Querfurth HW, LaFerla FM (2010) Alzheimer's disease. N. Engl. J. Med. 362, 329-344.

Rezvani HR, Dedieu S, North S, Belloc F, Rossignol R, Letellier T, de Verneuil H, Taïeb A, Mazurier F (2007) Hypoxia-inducible factor1alpha, a key factor in the keratinocyte response to UVB exposure. J. Biol. Chem. 282, 16413-16422.

Rothman SM, Mattson MP (2010) Adverse stress, hippocampal networks, and Alzheimer's disease. Neuromolecular Med. 12, 56-70.

Sakono M, Zako T (2010) Amyloid oligomers: formation and toxicity of Abeta oligomers. FEBS J. 277, 1348-1358.

Sarkar S, Das N (2006) Mannosylated liposomal flavonoid in combating age-related ischemia-reperfusion induced oxidative damage in rat brain. Mech. Ageing Dev. 127, 391-397.

Schönknecht $P$, Lütjohann $D$, Pantel J, Bardenheuer $H$, Hartmann $T$, von Bergmann K, Beyreutherd K, Schröder J (2002) Cerebrospinal fluid 24S-hydroxycholesterol is increased in patients with Alzheimer's disease compared to healthy controls. Neurosci. Lett. 324, 83-85.

Selkoe DJ (1991) Amyloid protein and Alzheimer's disease. Sci. Am. 265, 68-71.

Selkoe DJ (1994) Normal and abnormal biology of the $\beta$-amyloid precursor protein. Annu. Rev. Neurosci. 17, 489-517.

Smith MA, Zhu X, Tabaton M, Liu G, McKeel DW Jr, Cohen ML, Wang $X$, Siedlak SL, Dwyer BE, Hayashi T, Nakamura M, Nunomura A, Perry G (2010) Increased iron and free radical generation in preclinical Alzheimer disease and mild cognitive impairment. J. Alzheimers Dis. 19, 363-372.

Sottero B, Gamba P, Gargiulo S, Leonarduzzi G, Poli G (2009) Cholesterol oxidation products and disease: an emerging topic of interest in medicinal chemistry. Curr. Med. Chem. 16, 685-705.

Sparks DL, Schreurs BG (2003) Trace amounts of copper in water induce beta-amyloid plaques and learning deficits in a rabbit model of Alzheimer's disease. Proc. Natl Acad. Sci. USA 100, 1106511069.

Tamagno E, Aragno M, Parola M, Parola S, Brignardello E, Boccuzzi G, Danni O (2000) NT2 neurons, a classical model for Alzheimer's disease, are highly susceptible to oxidative stress. Neuroreport 11, 1865-1869.

Vega GL, Weiner MF, Lipton AM, von Bergmann K, Lütjohann D, Moore C, Svetlik D (2003) Reduction in levels of 24S-hydroxycholesterol by statin treatment in patients with Alzheimer disease. Arch. Neurol. 60, 510-515.

Vejux A, Lizard G (2009) Cytotoxic effects of oxysterols associated with human diseases: induction of cell death (apoptosis and/or oncosis), oxidative and inflammatory activities, and phospholipidosis. Mol. Aspects Med. 30, 153-170.

Verdier Y, Zarándi M, Penke B (2004) Amyloid beta-peptide interactions with neuronal and glial cell plasma membrane: binding sites and implications for Alzheimer's disease. J. Pept. Sci. 10, 229-248.

Zhu X, Su B, Wang X, Smith MA, Perry G (2007a) Causes of oxidative stress in Alzheimer disease. Cell. Mol. Life Sci. 64, 2202-2210.

Zhu X, Lee HG, Perry G, Smith MA (2007b) Alzheimer disease, the two-hypothesis: an update. Biochim. Biophys. Acta 1772, 494-502.

Zoccarato F, Valente M, Alexandre A (1993) Identification of an NADH plus iron dependent, $\mathrm{Ca} 2+$ activated hydrogen peroxide production in synaptosomes. Biochim. Biophys. Acta 1176, 208-214. 